\title{
The Indian Supreme Court's identity crisis: a constitutional court or a court of appeals?
}

Tarunabh Khaitan

Faculty of Law \& Wadham College, University of Oxford, Oxford, UK; The University of Melbourne, Melbourne Law School

This article was first published in: (2020) 4(1) Indian Law Review, 1-30

\section{ABSTRACT}

This article presents an empirical analysis of the Supreme Court's discretionary appellate jurisdiction (triggered by a "special leave petition" or "SLP"). Based on an analysis of 1100 randomly selected civil SLP cases spread over 11 years, it argues that its expansive SLP docket has cannibalized the Court's role as an e 
down legislation and constitutional amendments, ${ }^{3}$ and its unrelenting control over judicial appointments. ${ }^{4}$

With such a powerful apex court entrusted with a clear mandate to defend the ,$^{5}$ one might be forgiven for thinking that India's was in safe hands. ${ }^{6}$ This, unfortunately, is not the case. In this article, I will show that the SC's appellate function has decimated its capacity to function as an e ective constitutional court. I will argue that this skewing away from its constitutional function, towards an overwhelmingly appellate docket, has been exacerbated by in uential - and very expensive - lawyers o cially designated as "senior advocates". 7

Section II of this article shows that the bulk of the SC's work today comprises ordinary appellate matters rather than constitutional issues, caused mainly by a generous policy of admitting "special leave petitions" (hereinafter, 'SLP's). The impact of the expanding appellate docket of the SC on its constitutional watchdog function has been devastating. Constitutional cases are frequently delayed, decided by benches smaller than constitutionally mandated, and sometimes poorly reasoned and in ignorance of established precedents. Section III sets out the research design and the methodology for an empirical analysis of the relation between the admission and nal success of SLPs on one hand, and several independent variables on the other. The goal is to see whether any of these independent variables - such as the presence of a senior advocate before the admitting bench or the size of the admitting bench - is a factor in the likelihood of an SLP's admission or its nal success. Comparing the eventual success or failure of admitted cases alongside these independent variables further reveals whether any signi cant variable is acting as a good predictor at the admission stage (i.e. by increasing the admissibility of those cases that are more likely to eventually succeed) or a bad predictor (i.e. by increasing the admissibility of false positives that end up clogging the system but are eventually dismissed, or by decreasing the admissibility of false negatives that should have been admitted but were not).

Section IV examines our dataset of 1,100 cases to show that the duration for which these admitted cases remain pending on the SC's docket is substantial. The median admitted SLP typically takes four years and four months from its date of ling beforethe SC until its nal disposition. The cost of judicial delays to a respondent is exacerbated by the grant of interim relief in admitted cases. At least in the case of false positives, i.e. cases that were wrongly admitted, the net process costs for the system are also signi cant. $^{8}$

Section V will examine the judicial standards probably being applied to admission decisions by the Indian SC. We will nd that the Court has a relatively generous

\footnotetext{
${ }^{3}$ Kesavananda Bharati v State of Kerala (1973) 4 SCC 225; Sudhir Krishnaswamy, Democracy and Constitutionalism in India: A Study of the Basic Structure Doctrine (OUP 2011).

${ }^{4}$ Supreme Court Advocates-on-Record Association and Another v Union of India (2016) 5 SCC 1; Second Judges' case; Anashri Pillay, 'Protecting Judicial Independence through Appointments Processes: A Review of the Indian and South African Experiences' (2017) 1 Indian Law Review 283.

${ }^{5}$ See generally, arts 13, 32, 131, 132, 143 and 145(3) of the Constitution.

${ }^{6}$ This is not to suggest thatcourts alone should seekto defend a constitution. Even when well-designed and willing, their ability to do so is arguably limited: see generally, Tom Gerald Daly, The Alchemists: Questioning Our Faith in Courts as Democracy-Builders (CUP 2017). Cf Sam Issacharo , Fragile Democracies: Contested Power in the Era of Constitutional Courts (CUP 2015). I only assume that in the Indian constitutional framework, the SC has been entrusted with the role of being a constitutional watchdog - a role that, I will argue, it is failing miserably to perform.

${ }^{7}$ Marc Galanter and Nick Robinson, 'India's Grand Advocates: A Legal Elite Flourishing in the Era of Globalization' (2013) 20 International Journal of the Legal Profession 241.

${ }^{8}$ Notall admitted petitions that eventually result in dismissal are false positives. Sometimes there are good reasons for a court to admit an appeal only to dismiss it, for example when it wishes to clarify the law.
} 
admission practice, which appears to be contrary to the supposedly exceptional doctrinal standard for admitting SLPs, and also seems to be high compared to some other apex courts exercising discretionary appellate jurisdictions.

In section VI, we will nd that the presence of a senior advocate (representing either party) during an admission hearing has a statistically signi cant, positive, relationship with the likelihood of the case being admitted for a regular hearing; and that it is a bad predictor for the likelihood of eventual success of the case. Senior advocates are a signi cant contributor to the transformation of the SC from a constitutional court to an appellate court. They also substantially increase the process costs of SLPs without any substantive payo s.

Finally, in section VII, this article will outline a series of reform proposals that will allow the SC to better manage its SLP jurisdiction and better discharge its duty as a constitutional watchdog. With respect to salvaging its constitutional function, the paper will endorse the proposals to institutionally bifurcate the SC into an appellate division - to sit in four zonal benches around the country - and a constitutional division. On case management, it will propose a consideration of either a total ban on the appearance of senior advocates for admission hearings, or a move to admission decisions based on written briefs for the vast majority of civil SLPs.

\section{A staggering appellate docket}

\section{A. Appellate and constitutional jurisdictions of the SC}

Despite the vast scope of its constitutional powers, the SC's allocation of labour between its appellate and constitutional roles is strikingly lop-sided, in favour of the former. Let us rst understand the contours of this division of labour. ${ }^{9}$ The appellate jurisdiction of the SC - excepting its explicitly appellate jurisdiction - can be divided up in three categories ${ }^{10}$ :

(i) The SC's

extends to

(a) mandatory appeals, under speci c circumstances, against a sentence of death or imprisonment for life or for more than ten years ${ }^{11}$; and

(b) appeals upon the grant of a certi cate to appeal by a High Court stating that the criminal case "is a $\mathrm{t}$ one for appeal to the Supreme Court". ${ }^{2}$

(ii) The SC's comprises appeals upon the grant of a certi cate to appeal by a High Court stating that the civil case involves "a substantial question of law of general importance" which "needs to be decided by the Supreme Court'13 as well as numerous statutory appeal provisions. ${ }^{14}$

\footnotetext{
${ }^{9} \mathrm{Apart}$ from its constitutional and appellate jurisdictions, the SC also enjoys an advisory jurisdiction under art 143, if the President chooses to consult it on a matter of 'public importance'.

${ }^{10}$ The list is not exhaustive, as many statutes also permit appeals to the Supreme Court. See generally, Raeesa Vakil, 'Jurisdiction' in Sujit Choudhry, Madhav Khosla, and Pratap Bhanu Mehta (eds), The Oxford Handbook for the Indian Constitution (Oxford Handbooks Online 2017) ch 21. See also Mary Kozlovski, 'A Brief Introduction to the Indian Judicial System and Court Hierarchy' (Asian Law Centre, Melbourne Law School, Brie ng Paper No 12) <https://law.unimelb. edu.au/_data/assets/pdf_le/0005/3085178/India-Brie ng-Paper_nal.pdf> accessed 14 January 2020.

${ }^{11} \mathrm{Art} 134(1)$ read with the Supreme Court (Enlargement of Criminal Appellate Jurisdiction) Act 1970.

${ }^{12}$ Art 134(1)(c).

${ }^{13}$ Art 133(1).

${ }^{14}$ The Supreme Court of India, 'Indian Judiciary: Annual Report 2017-18 (The Supreme Court of India, New Delhi 2018), $52<$ https://www.sci.gov.in/pdf/AnnualReports/Annual\%20Report\%202018-light.pdf> accessed 14 January 2020 (The Supreme Court of India 2018 Annual Report).
} 
(iii) The SC's discretionary allows appeals by "special leave" against any order passed by any court (other than a military court) in India. ${ }^{15}$ These only occasionally concern constitutional matters, the typical SLP is not constitutionally salient. ${ }^{16}$

The SC's constitutional jurisdiction comprises:

(i) an

in disputes between the federal government and a state government, or between state governments, ${ }^{17}$

(ii) $\mathrm{a}$ if the High Court certi es that the case involves "a substantial question of law as to the interpretation of [the] Constitution", 18

(iii) $\mathrm{a}$

to enforce any fundamental rights guaranteed by the . ${ }^{19}$ The writ jurisdiction is original as well as appellate.

Although the SC sits in benches rather than , it is obliged to decide any case "involving a substantial question of law as to the interpretation of [the] Constitution" through a bench comprising ve or more judges (hereinafter, a "constitution bench"). ${ }^{20}$ The "substantiality" requirement means that not all constitutional cases are caught by this mandate.

\section{B. Size and shape of the SC's docket}

The docket of the SC comprises "admission matters" and "regular hearing matters." Admission matters mainly arise out of petitions seeking to invoke the SC's special leave jurisdiction or its writ jurisdiction (a small proportion concern other matters, such as those invoking its review or contempt jurisdictions). Admission matters constitute the bulk of the docket of the SC, which spends two of every ve working days of every week determining these matters. Each SC admissions bench (usually of two or three judges hereinafter, an "ordinary bench") typically decides between 30 and 60 admission matters in a day, with hearings often lasting no more than a few minutes for a case. ${ }^{21}$ Judges often do not give any reason for admitting or dismissing a petition. Only if an SLP or a writ

\footnotetext{
${ }^{15}$ Art 136.

${ }^{16}$ Chandra and others nd that only $3.9 \%$ of the (admitted) SLPs in their study involved a constitutional challenge: Aparna Chandra, William H J Hubbard and Sital Kalantry, 'The Supreme Court of India: A People's Court?' (2017) 1 Indian Law Review 145, 158 (Table 2). They also nd that the Court probably applies a lower admissions standard to constitutional SLPs compared to non-constitutional SLPs (at p. 167). Even so, a less than $4 \%$ docket share suggests that the bulk of the SLP adjudication e ort is spent on non-constitutional matters.

${ }^{17}$ Art 131.

${ }^{18}$ Art 132(1).

${ }^{19}$ Art 32. Chandra and others (n 16) 147 n 9 note: 'Article 32 petitions go through an admissions process similar to SLPS. Article 32 petitions are listed along with SLPs for admission every Monday and Friday. During the admissions hearing, the judges decide whether or not to admit that case based on a variety of factors, including but not limited to, whether the petition disclosesa primafacieviolation of afundamental right, whether the matterisjusticiable, whetherthecase should be barred by laches, etc.'

${ }^{20}$ Art 145(3).

${ }^{21}$ Arecentstudy found that the timespent onhearing the median civil SLP was 93seconds, or 1.55minutes: R Hemrajani and H Agarwal, 'A Temporal Analysis of the Supreme Court of India's Workload' (2019) 3 Indian Law Review 125, 148. The study does not distinguish between admission or regular hearings, so the likely time for the median admissions SLP is probably much lower.
} 
petition/appeal is admitted does it join the list of pending regular hearing matters (rarely, the matter is heard and decided substantively on the admission day itself). Theremaining three days of the working week are spent on regular hearings.

The SC has a large docket by the standards of any court, let alone an apex court. For a brief quantitative overview of aggregate numbers, we will focus on the year 2011 for two reasons. First, it was the last year of analysis in Nick Robinson's comprehensive study of the SC's workload that I am going to rely on. ${ }^{22}$ Second, it is the last year included in the 11-year empirical analysis conducted for this article. In 2011, 68,020 new admission petitions were led before the SC, whereas only 9,070 newly instituted cases in that year were regular hearing matters. Added to these 77,090 new cases were the 54,562 cases pending from the previous year. In 2011, the SC disposed of 67,131 admission matters and 6,002 regular hearing matters. ${ }^{23}$ It bears noting that the total number of petitions being instituted for admission before the SC dropped signi cantly in 2017 (to 50,104) and further still in 2018 (35,142). It is unclear whether this dramatic decline is due to a change in the system of counting new institutions or a real change - if so what has caused it - and whether it is likely to continue, stabilize, or start increasing again. At any rate, the absolute numbers remain very large, and the impact of these drops on the size of the pending docket has been marginal. ${ }^{24}$ By all accounts, pendency and docket size remains as big a problem today as it was in $2011 .^{25}$ These numbers demonstrate a remarkable feat, even for a court of a sanctioned strength of 34 judges (the actual number of judges has, until recently, been somewhere in the 20s), who typically sit in benches of two, three or ve judges. Given India's billion-plus population, the per capita litigation rate before the SC may well be very small. However, in absolute terms, the number of cases passing through a single judicial body - an apex court at that - is staggering. To put the gures in comparative perspective, the Canadian Supreme Court agreed to hear 53 appeals from 509 applications in 2013, whereas the US Supreme Court admitted 82 of 8,800 petitions seeking to invoke its discretionary appellate jurisdictionin 2009-10. ${ }^{26}$

Of the newly-instituted cases added to the docket of the SC in 2011, 84.6\% were SLPs, $1.8 \%$ were writs, and $3.1 \%$ were other appellate matters. ${ }^{27}$ The share of writ petitions in the admissions docket in 1985 , by contrast, was $41 \% .^{28}$ About three-quarters of the SLPs tend to relate to civil matters, and only one-quarter to criminal matters. ${ }^{29}$ Thus, the

\footnotetext{
${ }^{22}$ Nick Robinson, 'A Quantitative Analysis of the Indian Supreme Court's Workload' (2013) 10 Journal of Empirical Legal Studies 570.

${ }^{23}$ The Supreme Court of India 2018 Annual Report (n 14) 75.

${ }^{24}$ See The Supreme Court of India, 'Indian Judiciary: Annual Report 2018-19' (The Supreme Court of India, New Delhi 2019), 81, 83 <https://main.sci.gov.in/pdf/AnnualReports/Supreme\%20\&\%20High\%20Court_AR_English_2018-19. pdf> accessed 14 January 2020.

${ }^{25}$ On the SC's docket size and judicial delays generally, see Harish Narasappa and Shruti Vidyasagar (eds), State of Indian Judiciary: A Report by Daksh (Eastern Book Company 2016); Alok Prasanna, Ameen Jauhar and Faiza Rahman, 'Consultation Paper on the Supreme Court's Burgeoning Backlog' (Vidhi Centre for Legal Policy 2015) <https:// vidhilegalpolicy.in/reports/2015/10/1/consultation-paper-on-the-supreme-courts-burgeoning-backlog> accessed 14 January 2020; Alok Prasanna and others, 'Towards an E cient And E ective Supreme Court' (Vidhi Centre for Legal Policy 2016) <https://vidhilegalpolicy.in/reports/2016/2/8/towards-an-e cient-and-e ective-supreme-court> accessed 14 January 2020.

${ }^{26}$ Benjamin Alarie and Andrew J Green, Commitment and Cooperation on High Courts: A Cross-Country Examination of Institutional Constraints on Judges (OUP 2017) 153.

${ }^{27}$ Robinson (n 22) 584.

${ }^{28}$ ibid.

${ }^{29}$ ibid.
} 
docket of the SC is dominated by civil SLPs. The bulk of its caseload is taken up by its supposedly exceptional special leave jurisdiction, which typically does not concern a substantial constitutional question. ${ }^{30}$ A recent study of all reported SLP judgements over four recent years found that only 156 out of 4,834 judgements involved a constitutional challenge of any description. ${ }^{31}$

The constituent assembly had assumed that the SC would exercise its special leave jurisdiction cautiously and would evolve principles to guide its discretion in granting special leave to appeal. ${ }^{32}$ The SC has failed to live up to both of these hopes. Not only does it invoke this special jurisdiction with astonishing liberality, it has consistently refused to frame any meaningful guidelines to constrain its discretion. In 2010, a two-judge bench of the SC itself lamented the absence of guidelines governing its special leave jurisdiction, and called for the constitution of a ve-judge bench to issue some guidelines. ${ }^{33}$ However, in 2016, a ve-judge bench refused to issue any guidelines to guide its discretion. ${ }^{34}$ Undeterred, another three-judge bench - only six months after the ve-judge bench's order - sent the issue back to another constitution bench. ${ }^{35}$

All that exists by way of a "guideline" is that the bar for admission is supposed to be really high - that leave shall not be granted "unless it is shown that exceptional and special circumstances exist, that substantial and grave injustice has been done and that the case in question presents features of su cient gravity to warrant a review". ${ }^{36}$ Thus, at least in theory, a judge hearing an admissions petition must apply her mind after hearing the arguments to decide whether this high standard has been satis ed. If not, she must dismiss the petition. It is hard to express the standard numerically, but it should be clear that the exceptional-and-special-circumstances standard is a lot more demanding than a reasonable-prospect-of-success standard. In other words, the fact that an appeal ismore likely to succeed than not is not su cient reason to admit an SLP. The case must be exceptional, and the potential injustice grave - a mere error in law or fact by the High Court is not enough. Admission decisions by other apex courts are normally based on factors such as the importance of the case (for norm-setting or norm-clarifying purposes) as well as its likelihood of success. The bulk of SLP adjudication is not geared towards norm-correction but towards error-correction in particular cases. ${ }^{37}$ We can safely assume that, in India, the main criterion for admissibility of an SLP is not the normative importance of the case, but the potential injustice to the party caused when an exceptionally wrongly decided case is allowed to stand. Thus, I will assume that the main, even if not the only, factor relevant to an SLP admission decision in practice is the probability that the lower court's ruling will be reversed.

\footnotetext{
${ }^{30}$ Technically, High Courts have the powerto certifyacase if it is tfor appeal to the Supreme Court. In practice, the ease of ling SLPS, combined with the fact that Rule 1, Order XXI of the Supreme Court Rules 2013 provides a shorter window for ling an SLP in cases where a High Court refused this certi cate, encourages litigants to not even seek a High Court's certi cate, and simply le an SLP instead.

${ }^{31}$ Chandra and others (n 16) 155, 158.

${ }^{32}$ Vakil (n 10) 371.

${ }^{33}$ Mathaiv George(2010) 4 SCC 358.

${ }^{34}$ Mathaiv George(2016) 7 SCC 700.

${ }^{35}$ Vasanthakumar v Bhatia (2016) 7 SCC 686.

${ }^{36}$ Pritam Singh $v$ The State [1950] SCR 453, [8], rea rmed by a constitution bench in Mathai v George (2016).

${ }^{37}$ Chandra and others (n 16) 148-9; Andrew Green and Albert H Yoon, 'Triaging the Law: Developing the Common Law on the Supreme Court of India' (2017) 14 Journal of Empirical Legal Studies 683, 685.
} 


\section{The impact of an SLP-dominated docket on the SC's constitutional watchdog role}

Before we look at the empirical analysis in this paper, some qualitative claims about the impact of the SC's SLP docket explosion are in order. The massive docket, and its domination by SLPs, creates a time-starved court, whose ability to discharge its traditional adjudicatory and constitutional functions comes under enormous pressure. Some of the systemic pathologies created by the phenomenon include:

(i) a Court that frequently gives poor or no reasons for its decisions, especially when sitting in ordinary benches of two or three judges;

(ii) a polyvocal Court that often ignores , especially when speaking through an ordinary bench ${ }^{38}$;

(iii) a Court that increasingly decides constitutionally salient matters through ordinary benches rather than the constitutionally mandated ve-judge constitutional benches; and

(iv) a Court that signi cantly delays deciding not only SLPs but also constitutionally critical cases.

In 2013, these damaging consequences were brought into sharp relief in an egregiousbut-not-atypical SC decision: a case concerning a challenge to the constitutionality of the criminalization of consensual homosexual conduct between adults under s 377 of the Indian Penal Code. In 2009, the Delhi High Court had struck down the criminalizationas unconstitutional. ${ }^{39}$ The State accepted the High Court's ruling and decided not to appeal. Even so, SLPs were led - including by persons who had no individual interest in the case and some of whom were not even litigants before the Delhi High Court - and admitted. Despite the case involving a challenge to primary legislation based on fundamental rights, it was not deemed constitutionally salient enough to be heard by a constitutional bench. It was simply not listed for years, and a two-judge bench's decision eventually materi- alized after about four and a half years. In an astonishingly poorly-reasoned judgement in - issued several months after the conclusion of the hearings, and on the day before the retirement of the presiding judge - the ordinary bench overturned the High Court order and recriminalised homosexual acts between consenting adults. ${ }^{40}$ The bench adopted a $\quad$ hypothesis - disregarding decades of judicial practice - and stated that the law could not be overturned because it only a ected "a miniscule fraction of the country's population" ${ }^{41}$ It is less likely that a larger bench would have made such a grievous error in law, at least not without inviting a strong dissent.

A few months after this judgement was issued, in a separate matter relating to transgender rights, another two-judge bench ruled that that discrimination based on sexual orientation and gender identity was indeed prohibited by the was deeply damaging to trans persons..$^{43} \mathrm{~A}$ few years later, in on a nine-judge bench castigated the ruling in . Their

\footnotetext{
${ }^{38} \mathrm{Green}$ and Yoon (n 37) 700. The Court's duty to do 'complete justice' under art 142 is often invoked to ignore relevant precedents.

${ }^{39}$ Naz Foundation v Govt. of NCT of Delhi (2009) 160 Delhi Law Times 277.

${ }^{40}$ Tarunabh Khaitan, 'Koushal v Naz: Judges Vote to Recriminalise Homosexuality' (2015) 78 Modern Law Review 672.

${ }^{41}$ Koushal v NAZ Foundation (2013) Civil Appeal No. 10972, [43].

${ }^{42}$ National Legal Services Authority v Union of India (2014) Writ Petition (Civil) No. 400, [83].

${ }^{43}$ ibid [116].
} 
insisted that the "

hypothesis is misplaced because the invasion of a fundamental right is not rendered tolerable when a few, as opposed to a large number of persons, are subjected to hostile treatment". ${ }^{44}$ Despite these inconsistent utterings, remained good law for ve years. Although "curative" petitions challenging were admitted, it was another constitution bench of ve-judges, in a separate challenge to the constitutionality of s 377, that nally overruled it. In its judgement, the constitutional bench described the reasoning of the 2013 bench as "perverse", 45 "highly unsustainable", 46 "retrograde", ${ }^{47}$ and "fallacious". ${ }^{48}$

The reasoning in the 2013 case was appalling by the SC's own admission. The 2013 bench simply ignored the entire constitutional practice of independent India which had, until then, assumed that the violation of a fundamental right of even a single individual was constitutionally signi cant. Two subsequent benches - one of co-equal strength - felt able to criticize the judgement in their obiter also signals the SC's institutional polyvocality. While an institutional recognition of its fallibility is a good thing, an apex court whose rulings are normally nal should try to reduce the instances of such egregious mistakes in the rst place. It is clear that this case should have been sent to a constitutional bench to begin with because the mandates it. Doing so could have saved a lot of judicial time spent in making a mistake, having it pointed out, and then correcting it. Sending constitutionally salient matters to ordinary benches to save judicial time is false economy. Finally, judicial delay in this important case was spectacular. The original writ petition challenging s 377 was led in the Delhi High Court in 2001. It took eight years for the High Court to nally decide the case in 2009. After recriminalisation by the 2013 bench, ittook another ve years for India's LGBTQ people to be nally decriminalized. Countless individuals were arrested, tortured, blackmailed, persecuted and harassed in the interim. A few lives were lost, some to suicides. ${ }^{49}$ Judicial delay is always bad for the parties. Delay in constitutional matters is bad not only for the parties, but also often for many others. This is not to suggest that larger benches always get things right - they clearly do not. Moreover, if they reach a wrong outcome, it is harder to overturn a ve-judge bench ruling. Even so, as Green and Yoon show, a larger bench is more likely to be sensitive to existing precedents, and therefore more likely to give judgements that are at least legally more palatable. ${ }^{50}$

The judgement is not an aberration - rather, it is symptomatic of the SC's functioning as a judicial institution. The poor quality of its reasoning is often remarked upon. Arguments made by parties are sometimes not recorded in the judgements, and occasionally - it has been alleged - even misrecorded. ${ }^{51}$ All too frequently, the actual prayers of the litigants are ignored, and the SC gives orders that no party before it prayed for - sometimes against persons who were not even heard by the SC. ${ }^{52}$ The SC often acts as

\footnotetext{
${ }^{44}$ Justice K.S. Puttaswamy (Retd.) v Union of India (2017) Writ Petition (Civil) No. 494, [146].

${ }^{45}$ Navtej Singh Johar v Union of India (2018) 10 SCC 1, [169].

${ }^{46}$ ibid [172].

${ }^{47}$ ibid [190].

${ }^{48}$ ibid [253].

49ibid [65], [42].

${ }^{50}$ Green and Yoon (n 37) 700.

${ }^{51}$ Gautam Bhatia, 'The Aadhaar Judgment and the Constitution - I: Doctrinal Inconsistencies and a Constitutionalism of Convenience' (Indian Constitutional Law and Philosophy, 28 September 2018) https://indconlawphil.wordpress.com/ 2018/09/28/the-aadhaar-judgment-and-the-constitution-i-doctrinal-inconsistencies-and-a-constitutionalism-of-conve nience/ accessed 14 January 2020.

${ }^{52}$ Anuj Bhuwania, Courting the People: Public Interest Litigation in Post-Emergency India (CUP 2017).
} 

law. ${ }^{53}$, never an especially strong feature of the SC, ${ }^{54}$ is arguably worse 0 today. ${ }^{55}$ Relevant, even binding, precedent is, far too often, simply ignored. Relevant legislative or even constitutional provisions are sometimes not even discussed in the judgement.

Most of these problems concern cases decided by small benches with two or three judges. In a recent empirical study, Green and Yoon found that for a large percentage of cases, "the Court does not cite any prior cases and, when it does, it does not cite many." 56 They also nd that "more legally grounded cases . . . tended to be decided by larger panels (panels of ve or greater)" ${ }^{57}$ Furthermore, judged by citation in future cases, "larger panels tend to have greater authority". ${ }^{8}$ This is why it is so problematic that the constitutional injunction that important constitutional issues be heard by a bench of at least ve judges is more or less ignored in practice. ${ }^{59}$ Constitution benches heard $15.5 \%$ of all disposed cases between $1950-4$, whereas the gure for $2005-9$ was $0.12 \%{ }^{60}$-this gure alone tells us much of what we need to know about the balance between the appellate and the constitutional functions of the SC.

The system also diverts the SC's attention away from key constitutional matters, resulting in substantial delay. For example, an elected government of the National Capital Territory of Delhi wasted most of its ve-year term in o ce, waiting for the SC to clarify the scope of its powers vis-à-vis those of the centrally appointed Lieutenant Governor. ${ }^{61}$ An electoral bonds scheme that gave enormous campaign nance advantage to the ruling party remained pending even as general elections were concluded in 2019, allowing this nancial advantage of dubious legality to be encashed electorally. ${ }^{62}$ A Delhi High Court's ruling on the applicability of transparency laws to the judiciary has been stayed since $2010 .{ }^{63}$ The very nature of democratic governance in India has come under strain because of the SC's inability to prioritize matters of grave constitutional signi cance.

\footnotetext{
${ }^{53}$ Chintan Chandrachud, 'Constitutional Interpretation' in Sujit Choudhry, Madhav Khosla and Pratap Bhanu Mehta (eds), The Oxford Handbook of the Indian Constitution (Oxford Handbooks Online 2016).

${ }^{54}$ Rajeev Dhavan, The Supreme Court under Strain: The Challenge of Arrears (Tripathi 1978) 450; Upendra Baxi, 'The Travails of Stare Decisis in India' in A RBlackshield (ed), Legal Change: Essays in Honour of Julius Stone (Butterworths 1983) 38; Nick Robinson, 'Structure Matters: The Impact of Court Structure on the Indian and U.S. Supreme Courts' (2013) 61 American Journal of Comparative Law 173.

${ }^{55}$ Nick Robinson, 'Judicial Architecture and Capacity' in Sujit Choudhry, Madhav Khoslaand Pratap Bhanu Mehta(eds), The Oxford Handbook of the Indian Constitution (Oxford Handbooks Online 2017) 340.

${ }^{56}$ Green and Yoon (n 37) 698.

57 ibid 700 .

${ }^{58}$ ibid 706.

${ }^{59}$ Article 145, Constitution of India. See also Nick Robinson, 'Bigger Bench Please' Indian Express (8 June 2012) <http:// www.indianexpress.com/news/bigger-bench-please/959194/> accessed 14 January 2020.

${ }^{60}$ Nick Robinson and others, 'Interpretation the Constitution: Supreme Court Constitution Benches since Independence' (2011) 45Economic \& Political Weekly 27. We should note, though, that 'constitution benches' do sometimes hear matters that are not 'constitutional'. For example, a ve-judge bench may be constituted to reconsider a judgement of a three-judge bench in a matter that does not relate to the Constitution - even so, such a bench will be called a constitution-bench. In reality, therefore, the decline in adjudication by constitution benches is an even bigger problem from the point of the constitution-defence function of the SC than these numbers might suggest. ${ }^{61}$ Government of NCT of Delhi v Union of India (2017) C.A. No. 2357.

${ }^{62}$ Gautam Bhatia, 'The Electoral Bonds Scheme is a Threat to Democracy' Hindustan Times (18 March 2019) <https://www. hindustantimes.com/analysis/the-electoral-bonds-scheme-is-a-threat-to-democracy/story-PpSiDdUjlw5WNBUzDsSzxl. html> accessed 14 January 2020; Gautam Bhatia, 'An Ine ectual Angel' The Hindu (29 April 2019) <https://www. thehindu.com/opinion/lead/an-ine ectual-angel/article26974278.ece?fbclid=IwAR1rhya1i0OHW-yIAMXKgXhU_ -34iTB4hjj3jabhtN4vI51BdIXwSV9yxJQ> accessed 14 January 2020.

${ }^{63}$ Manu Sebastian, 'SC vs RTI: SC's Stay of Delhi HC's Landmark Judgement Enters 9th Year' (22 January 2019) <https:// www.livelaw.in/columns/is-rti-act-applicable-to-judiciary-sc-decision-142313> accessed 14 January 2020.
} 
These features are not only due to the SC's enormous, SLP-skewed docket, but also contribute to it, forming a vicious cycle. Poorly reasoned, precedent-insensitive judgements not only invite further challenges and review petitions from the parties, they signal to all litigants that the system has very few legal certainties. Litigants are then incentivized to take a chance and hope for a sympathetic bench, driving up the number of SLPs led. As these numbers rise, the SC is compelled to make cuts elsewhere - since it remains unwilling to rein in its SLP jurisdiction. The main casualty is its constitutional defence function. The cycle is not just repeated but intensi ed over the years.

\section{Research design and methodology}

It follows then that to understand the failure of the SC to perform its constitutional function, we need a better understanding of the exercise of its SLP jurisdiction. In particular, we need to know how it exercises its discretion to admit or refuse to admit an SLP. Given that most orders concerning admissions of SLPs do not contain any reasons, and given the extremely large volume of these orders, a large- $\mathrm{N}$ quantitative analysis is likely to be a more fruitful approach for an exploratory study. The study would inquire into the lifecycle of a representative sample of SLPs, from their ling to their nal disposal, in order to identify broad patterns. Any such patterns could set the agenda for future research and generate some evidence-led tentative proposals for institutional reform.

The timeframe for selecting the case samples for the research had to be relatively recent, but not too recent. This is because the research was aimed at following the entire lifecycle of civil SLPs, from ling, to admission decision, to nal outcome after regular hearing. Given that a case can take several years after being admitted to be nally decided, I had to ensure that most of the cases in our dataset would have been decided by the time of the study. For this reason, a period of 11 years, between 2000 and 2011 was chosen for study.

The number of SLPs led in this period is in the hundreds of thousands, necessitating random sampling. After consulting statisticians, it was determined that 1100 randomly selected cases spread evenly across the period under study would su ce. Around 120 civil SLPs led in each of these 11 years were randomly selected and downloaded from the SC's o cial online repository https://www.sci.gov.in/daily-order. ${ }^{64}$ The SC's website has some errors and gaps, and sometimes orders in certain cases are missing. Therefore, of the 120 downloaded cases for each year, the rst 100 cases with a near-complete dataset were chosen for the study. ${ }^{65}$ This resulted in a dataset of 1100 cases. The entire lifecycles of these 1100 cases were then tracked down, from ling, to admission decision, and - if admitted - the nal decision after regular hearings. This dataset of 1100 cases were then hand-coded for 37 variables. ${ }^{66}$ These variables were extrinsic to the case, such as key dates (of ling, admission decision etc), nature of the lawyer before the court, subject-matter, size of the bench, nature of the parties, nal outcome and so on. Subjective variables intrinsic to the case, such as the quality of the judicial reasoning, were not coded. Even in our near-complete dataset, we found that information about some variables was

\footnotetext{
${ }^{64}$ This part of the research was automated using a software code written by Mohit Desai.

${ }^{65}$ The missing orders did not seem to followany discernible pattern, soleaving them out of the dataset is unlikely to have been material.

${ }^{66}$ Chandni Chawla did most of the coding, with cross-checks of a small sample by Amba Kak.
} 
occasionally missing from the record - for this reason, statistics relating to some variables will be based on the cases for which this information was available.

After coding, descriptive statistics were generated to test for possible relationships. If these statistics showed a possible correlation, regression analysis was conducted to check for signi cance. ${ }^{67}$ The next few sections highlight the key ndings of this empirical analysis.

\section{Delays and impact on parties}

In section II, we examined the systemic impact of the heavy SLP docket - the squeezing out of the constitutional protection role of the SC. In this section, we will look at the impact of the docket size and concomitant delays in adjudication on the litigants. The rst important nding of the study was that SLPs spend a long time in the judicial system. Table 1 below shows three time periods (in days). The rst row shows the time between the date of ling an SLP ( $\left.T_{1}\right)$ and the date on which the decision to grant or refuse leave was given $\left(T_{2}\right)$. The second row calculates the total time an admitted case took from its $\operatorname{ling}\left(a t T_{1}\right)$ until its nal disposal (at $\mathrm{T}_{3}$ ).

In the rst row, no SLP was admitted or dismissed on the day it was led ("Min") - the earliest an SLP can be dismissed is when it is rst listed before a bench, which is usually a few weeks after ling. The longest an SLP took to get from $T_{1}$ to $T_{2}$. was 4,227 days, i.e. a little over eleven and a half years ("Max"). The average number of days for this period was a bit under a year, i.e. 334 days ("Mean"). The average can, however, be distorted by outlier cases that took exceptionally long. The median is a more reliable gauge of how long a case typically takes. The median period from ling to an admission decision is a reasonable 71 days, but there are very signi cant variations - while the quickest third of the cases took only 34 days to get a decision on admission, the slowest third took almost a year. The second row shows that the median number of days an admitted case takes for a nal decision is 1602, i.e. about four years and four months. ${ }^{68}$ If they fell in the unlucky third quartile, the wait is much longer. These are very long time periods for parties to have to wait, especially given that this is an appeal, and that they are likely to have spent considerable time in lower courts already. ${ }^{69}$ Given that $T_{2}$ and $T_{3}$ almost always fall on di erent days, often separated by months if not years, the bench that nally hears an appeal is usually di erent from the one that admitted the petition. Figure 1 represents Table 1 in a visual form, showing that the median time for an SLP admissions decisions to

Table1. Time elapsed between the institution of an SLP( $\left.T_{1}\right)$, adecision on its admission $\left(T_{2}\right)$, and its nal disposal if admitted ( $T_{3}$ )

\begin{tabular}{|c|c|c|c|c|c|c|c|}
\hline Type & No.of Obs & Min & 1st Quartile & Median & Mean & 3rd Quartile & $\operatorname{Max}$ \\
\hline$T$ & 1088 & 0 & 34 & 71 & 334 & 334.2 & 4227 \\
\hline$T$ & 186 & 0 & 584 & 1602 & 1681 & 2499 & 6338 \\
\hline
\end{tabular}

\footnotetext{
${ }^{67}$ These analyses were conducted by Mohit Desai and Siru Wang.

${ }^{68}$ This nding corroborates a previous study, which found that the average time elapsed between the date when the appealeddecision was deliveredand thedateonwhich the SC nallygaveadecisiononitsmerits wasmore thanfour years and two months: Chandra and others (n 16) 154.

${ }^{69}$ Chandra and others claim, albeit on limited data, that a case typically takes $13 y e a r s$ and 6 months from being led in the court of rst instance to a nal substantive decision in the SC: Chandra and others (n 16) 155.
} 


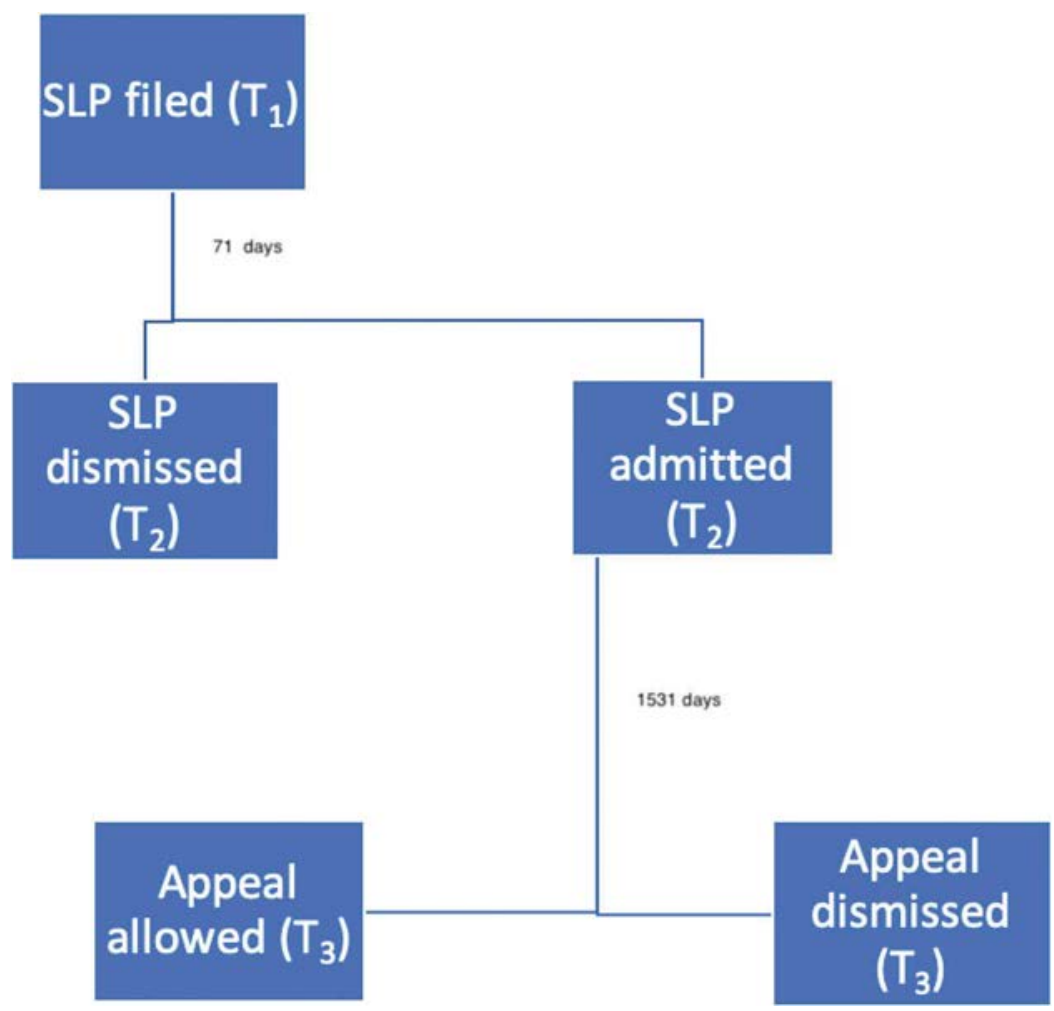

Figure 1. A median SLP's life in the SC

be taken from the ling date is 71 days; and that the median time after admission until nal disposal is 1,531 (1602-71) days.

The data on grant of interim relief had considerable gaps - of the 208 admitted cases, we could locate an order granting or refusing interim relief with any certainly only in 98 cases. It is telling, however, that of these 98 cases, interim relief was granted in 85 cases, and refused in only 13 cases. The numbers are too small to say anything conclusively on the SC's propensity to grant interim relief, but if corroborated, the SC seems very likely to grant some interim relief upon admitting a case. This compounds the respondent's process costs in icted by delays.

\section{The standard for admissibility}

Although the doctrinal standard that needs to be satis ed for the admission of an SLP is exceptionally high, once a civil SLP is admitted, the SC is supposed to act as a normal appellate court (rather than a deferential review court). In other words, it should decide the case on merits, applying the normal standard of success in civil litigation: balance of probabilities. In theory then, we should see almost all admitted civil cases succeeding when they are eventually decided.

Against this, previous empirical research has shown - albeit in another context - that reversal rates tend to settle around 50\% irrespective of the judicial standard being 
applied. ${ }^{70}$ The rationale is that

, parties typically prefer litigation over out-of-court settlement only in cases where their chance of victory is moreor-less 50\% (under the relevant judicial standard, whatever that might be). If they estimate their odds of winning to be signi cantly higher or lower, they are likely to settle instead, so the only cases that see litigation are typically evenly balanced. Two factors, however, suggest that this nding may not apply to SLPs. First, the predictability of the likelihood of a litigation victory is especially di cult in the Indian judicial system, given judicial polyvocality and insensitivity to . Under epistemic uncertainty, parties are more likely to litigate than to settle. Consequently, the cases that actually end up being litigated may not be selected based on their reversibility. Second, the objection applies in cases where parties alone decide whether the appeal is litigated - i.e., they concern cases where appeals are mandatorily heard by the court. SLPs, on the other hand, are subject to discretionary appeals. Even if we assume greater epistemic certainty among litigants (as regards the likelihood of success of their cases), the judicial lter at the admissions stage is supposed to let in only those cases where the likelihood of success is especially high. So, whatever strategic interests parties may have in a litigation proceeding, the ultimate decision on the matter rests with the SC. Thus, at least in discretionary appeals in apex courts, we should expect a reversal rate that is signi cantly higher than $50 \%$.

This seems to be borne out by some evidence. A study of the Israeli Supreme Court, for example, found the reversal rates in mandatory civil appeals (i.e. cases where the Court was obliged to hear the appeal) to be $32.9 \%$, but the rate for discretionary appeals was as high as $68.5 \% .^{71}$ The US Supreme Court, which also selects appeals after exercising its discretion, reversed or vacated $71.06 \%$ of the cases it admitted to hear between 1999 and 2008. ${ }^{72}$ The Australian High Court reversed 148 of 255 appeals between 2012 and 2017 - i.e. 58.04\%. ${ }^{73}$ These Australian numbers do not distinguish between discretionary appeals and appeals by right - the reversal rates for discretionary appeals alone is likely to be higher.

Indian conditions are no doubt di erent from the Australian, American, and Israeli ones. Even so, the reversal rates of these generalist apex courts should be indicative of what we could expect from an apex court that screens the cases it decides. If anything, given the widely acknowledged worries about the docket size of the Indian SC, it is plausible to expect it to be even more reluctant to exercise its special discretion to admit a case than its relatively under-worked counterparts. The point being made is simply this: Priest and Klein may well be right that we should expect a 50\% reversal rate irrespective of the standard of review applied by a court in mandatory-jurisdiction appeals. However, with respect to a discretionary appellate jurisdiction of apex courts that tend to focus on norm-clari cation rather than error-correction, a court is likely to screen cases with

\footnotetext{
${ }^{70}$ George L Priest and Benjamin Klein, 'The Selection of Disputes for Litigation' (1984) 13 Journal of Legal Studies 1, 17.

${ }^{71}$ Theodore Eisenberg, TaliaFisher and Issi Rosen-Zvi, 'Israel's Supreme CourtAppellate Jurisdiction: An Empirical Study' (2011) Cornell Law Review (Paper 190) 693, 714 <https://scholarship.law.cornell.edu/cgi/viewcontent.cgi?article= 1189\&context=facpub> accessed 14 January 2020.

${ }^{72}$ The gure is calculated based on Table 2available atRoyE Hofer, 'Supreme Court Reversal Rates: Evaluating the Federal Courts of Appeals' (2010) 2 Landslide <https://ipo.org/wp-content/uploads/2013/03/Supremecourtreversalrates.pdf> accessed 14 January 2020.

${ }^{73}$ Calculated based on data published by the High Court of Australia: High Court of Australia, 'Annual Report 2016-2017' (2017), 22 ( nal table on the page) <https://www.hcourt.gov.au/assets/corporate/annual-reports/HCA_Annual_ Report_2016-17.pdf> accessed 14 January 2020.
} 
a very high (rather than a merely reasonable) likelihood of success if admitted. Therefore, we should normally expect a higher reversal rate in such appellate courts. If we do not see such high reversal rates, some combination of the following factors might be at work: (i) the admitting court is applying a relatively permissive lter at the admissions stage, (ii) it is making admission decisions based on factors other than the likelihood that the case will succeed upon appeal, and (iii) that legal predictability in that jurisdiction is so low that even the admitting benches systematically get things wrong.

Figure 2 below shows the number of cases in our dataset in which the SC granted leave to appeal. In each of the 11 sets of 100 cases, we see that the SLP admission rate ranged from $35 \%$ to $8 \%$, but most of the other years were closer to the average admission rate of $18.9 \%$.

Of the 1,100 total cases that were studied, only 208 proceeded to the regular hearing stage. That gives us a mean admission rate of just under $19 \%$. This already seems to be a high number for a jurisdiction that is supposed to be "special and exceptional". Figure 3 shows the fate of these 208 admitted cases in our dataset on the date the results of this analysis were nalized:

We see that the appeal was allowed in 87 cases; partly allowed in 15 cases (i.e. the appellant got some of the reliefs they sought, but not all); ${ }^{74}$ and remanded in 5 cases (which, arguably, is still a win of sorts for the appellant, who gets the chance to litigate the case once again). In all these 107 cases, the appellant got something out of the SC's order. Therefore, for simplicity's sake, they will be deemed to be cases in which the appeal was allowed, i.e. where the High Court's order was reversed. Thus, the post-admission

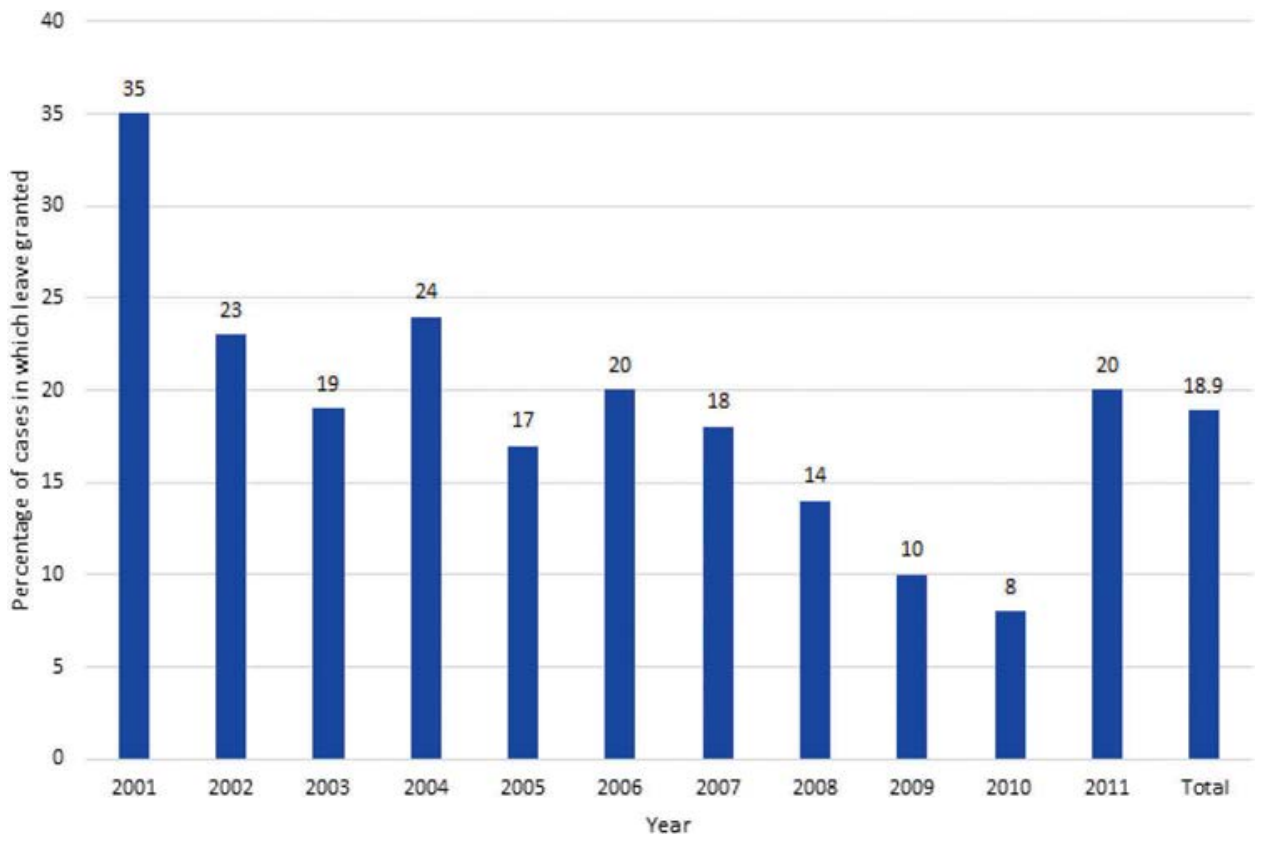

Figure 2. SLP admission rates

\footnotetext{
${ }^{74}$ The 'partly allowed' category includes 2 cases where the SC neither allowed nor dismissed the appeal but gave a di erent order in favour of the appellant.
} 


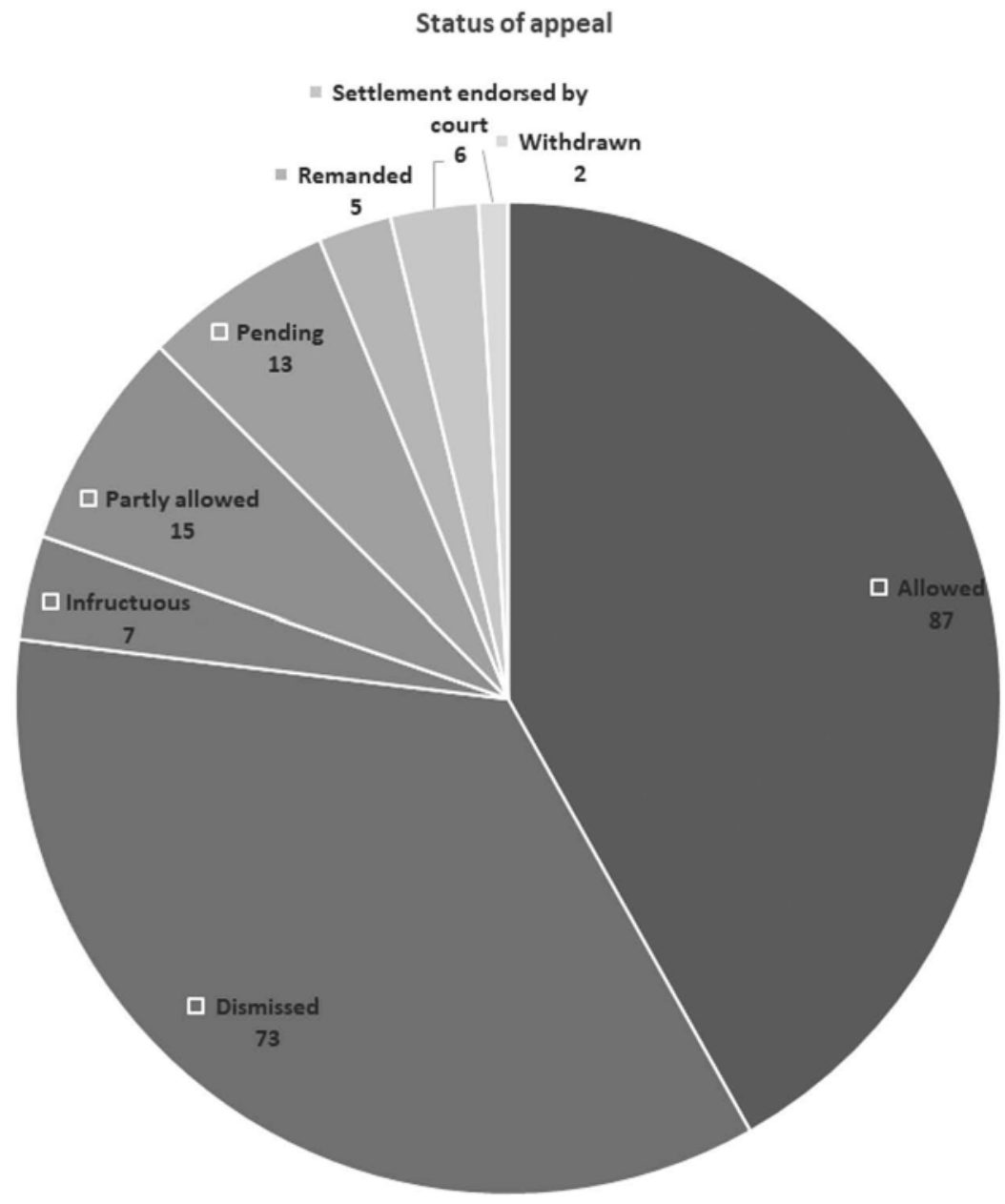

Figure 3. Final decision on admitted SLPS

analysis in this paper was informed only by these 107 "successful" cases (where the appeal was "allowed") and the 73 cases where it was dismissed. The remaining cases (that were still pending, became infructuous, or were withdrawn) were ignored. So were the 6 cases in which the parties settled between themselves and had that settlement endorsed by the SC - after all, we are interested in judicial behaviour, rather than simply whether the appellant pro ted from ling the SLP. ${ }^{75} 107$ successful cases out of a total of 180 (107 + 73) gives us an average reversal rate of 59.4\%. ${ }^{76}$ Given the high threshold for admitting an SLP, this is a relatively low reversal rate. We saw that the reversal rate in the Israeli and US Supreme Courts is in the region of $70 \%$ or so. The reversal rates in India are relatively low, which appear to signal an unduly high admission rate. Furthermore,

\footnotetext{
${ }^{75}$ It is unclear whether the respondent settled for substantive reasons (i.e. because the appellanthad agood chance of winning) or out of frustration for the long-drawn legal process. As such, the mere fact of settlement does not tell us anything about how the nal judgement might havegone.

${ }^{76}$ Sometimes appellate courts agree with the lower court's order, butfor di erent reasons. We do not count such orders as reversals because we are interested in what the appellant is likely to view as 'success'.
} 
determining whether the admission rate in a court is too high is not entirely a matter of proportions and percentages. Every human institution has its limits - a Court with 30- odd judges can reasonably be expected to do due judicial diligence in only so many cases. While I do not have any basis to suggest an absolute maximum number of cases that the SC should hear in any given year, most reasonable observers should nd it easy to conclude that its current workload is way beyond any such maximum threshold.

The relatively low reversal rate of the SC suggests that some combination of the following factors is probably at work: (i) unlike other highly selective apex courts that focus on norm-clari cation - the SC seems to apply a lower reasonable-prospect-ofsuccess standard to determine the admissibility of SLPs in practice, instead of the doctrinally mandated exceptional-and-special-circumstances standard, and using inter-nal factors other than likelihood of success in making admission decisions, (ii) it is (at least sometimes) making admission decisions based on external predictors, and (iii) even the SC judges cannot reasonably predict the nal outcome of the case due to the radical uncertainty in Indian law. The precise role of each of these factors is di cult to determine, but it is probable that they are all contributing factors. In the next section, we will examine on the second possibility: that admission decisions are made, at least sometimes, based on external predictors.

\section{Use of external factors in admission decisions}

The determination of the admissibility of an SLP is supposed to be judicial, based on the merits of the case. ${ }^{77}$ As such, we should not expect any variable external to the case - such as the nature of the party or the advocate before the SC - to make a di erence to the decision to admit or dismiss a petition.

Looking at the practice of SLPs, the sheer volume of the petitions led, the fact thata bench makes admission decisions on 30-60 cases per day, often after hearing each case for a few minutes, it is highly likely that human judges will end up relying - perhaps sub-consciously on external indicators of the gravity and exceptional character of a case. It is also likely, if these factors are bad predictors - that is, if they do not truly represent the merit of the case - that the eventual reversal rate in admitted cases would be a lot lower than what doctrinal standards would have us expect, unless the nal outcome of a case was itself being determined by reliance on external factors. This is less likely because unlike admission decisions, most nal judgements are delivered after detailed judicial hearings and arguments. ${ }^{78}$ Based on several conversations with practitioners and academics, existing literature, and a pilot project of 300 randomly selected cases, ${ }^{79}$ it seemed that the following external factors could be a ecting admissions decisions by the Court: (i) nature of the parties before the SC, (ii) size of the admissions bench and/or the presence of the Chief Justice on it, (iii) representation of either party by a senior advocate, and (iv) the subject matter of the dispute.

These are some of the most visible external features of a case. It is plausible to assume that a time-poor bench struggling to decide an admissions matter on its substance is likely to prefer the use of a visible predictor of a less-obvious predictor: it is hardly worth

\footnotetext{
${ }^{77}$ Vasanthakumar v Bhatia (2016) Writ Petition (Civil) No. 36, [20].

${ }^{78}$ This does not mean that the nal judgements are necessarily well-reasoned and based on precedents. Often, they are not. The point simply is that there is less need for a judge to rely on external factors during a nal hearing.

${ }^{79} \mathrm{Amba} \mathrm{Kak}$ provided invaluable assistance for the pilot study, especially in coding and helping analyse these 300 cases.
} 
using a predictor if its identi cation takes as long as a substantive decision. It may be that none of these factors is being used as a predictor, that remains to be seen. But if an external predictor is being used to save time, it is likely to be a highly visible one.

Does the SC use external factors as predictors of eventual success of the appeal in order to make decisions about admissibility? We cannot properly answer that question through a quantitative study alone, but we can check for any positive relationships between admissibility and these external factors. An admissions bench is supposed to determine the likelihood of an SLP's success as well as the level of injustice that non-admission might cause based on the substantive merits of the case. We have hypothesized that, given the size of the admission docket and human limitations, it is probable that the SC relies on certain external factors to make this determination. In this section, I will rst present descriptive statistics for the relationship between each of these variables and our dependent variable (i.e. whether the case was admitted or dismissed), before subjecting these potential relationships to regression analysis. The main independent variable excluded from the following analysis is the o cial 'subject matter' classi cation of the SLP. The SC uses over 300 categories to classify SLPs. Even so, a large portion of our sample fell in the 'other' category, and the number of SLPs that fell within substantive subjects tended to be small. A much larger dataset than 1100 cases is required to say anything meaningful about the potential relationship between o cial subject matter classi cation and admis- sion rates.

In Figure 4 we see that in 766 of the 1,100 cases in our dataset, none of the parties were represented by a senior advocate during the admissions hearing. In 211 cases only the appellant, or at least one of the appellants, was represented by a senior advocate. In 58 cases, only a respondent, or at least one of the respondents, was so represented, and in 65 cases both sides were represented by a senior advocate. $13.7 \%$ of 766 cases (i.e. 105 cases) were admitted without the intervention of any senior advocate, whereas 113 admitted cases saw at

\section{SA at Admission}

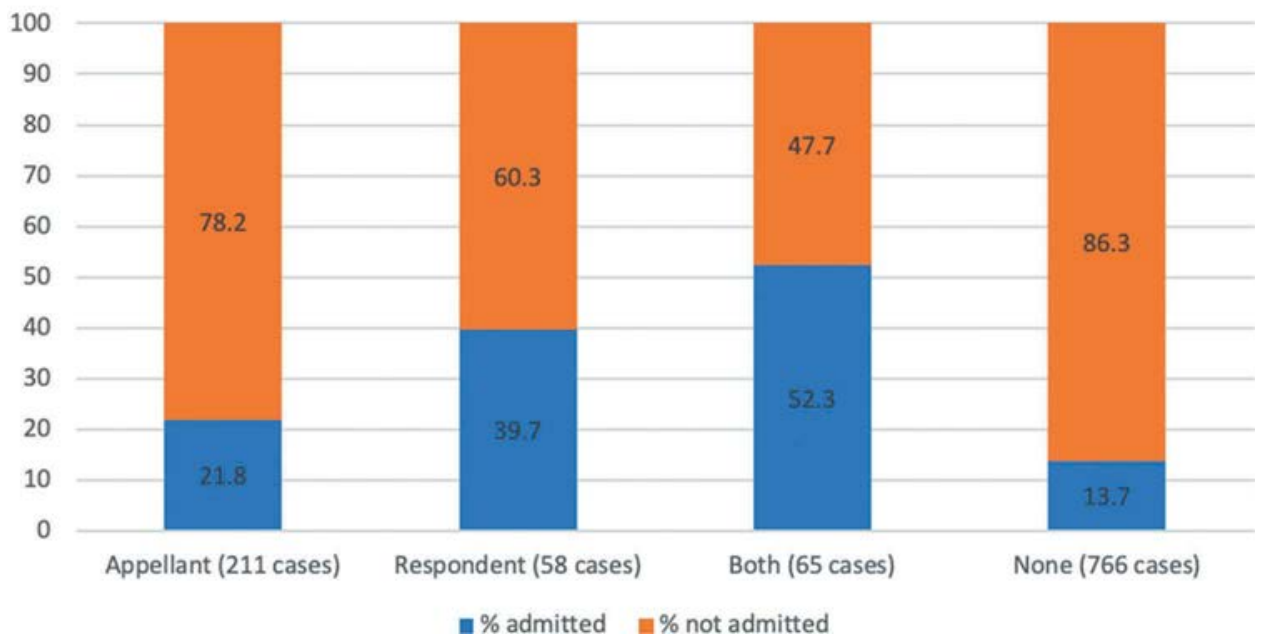

Figure 4. Relation between representation by a Senior Advocate during admissions hearing on the admission rate 


\section{Chief Justice on Bench}

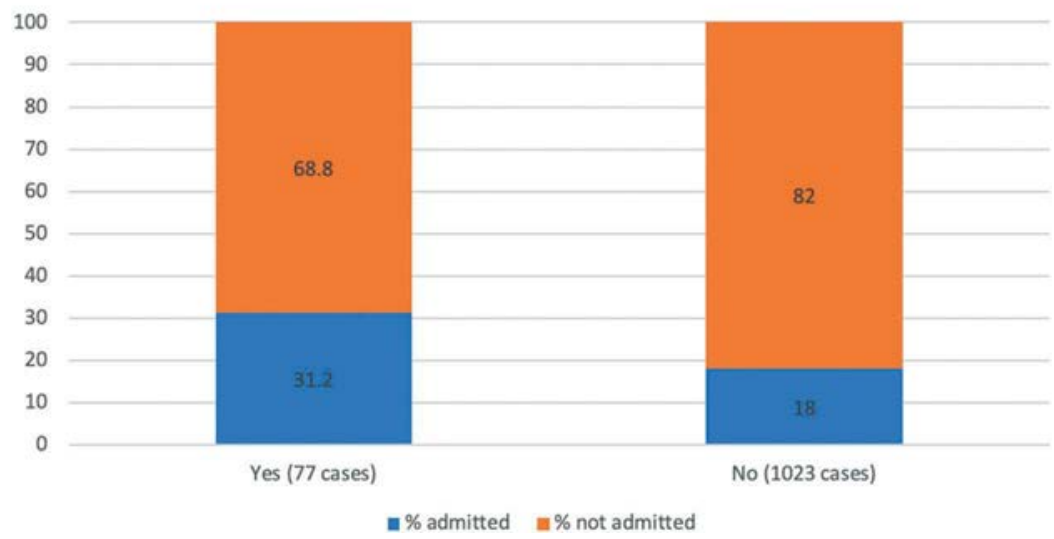

Figure 5. Relation between the Chief Justice's presence on admissions benchon the admission rate

least one senior advocate before the SC at the admission hearing. In other words, roughly half of the admitted cases are routed to the regular hearing docket through a senior advocate's intervention. This is a surprisingly high proportion, given how expensive senior advocates are for litigants.

Figure 4 also shows the admission rate of cases when a senior advocate was present. The SC was most likely to admit a case for regular hearing in cases where both sides were represented by senior advocates at the admissions hearing - this gure in our study was a very high 52.3\%. The next highest rate of admission was for those cases where only the respondent was represented by a senior advocate, at $39.7 \%$. This is surprising because a respondent's senior advocate's opposition to the admission of the leave petition is correlated with a likelihood that the petition will be admitted. In cases where a senior advocate present before the SC was representing an appellant, the admission rate was $21.8 \%$, which despite being lower than the previous two gures, is still signi cantly higher than the admission rate in cases where there was no senior advocate before the SC (which was merely 13.7\%). Comparing these numbers against the average admission rate across 1,100 cases $(18.9 \%)$, it seems that the presence of a senior advocate, for whichever party, increases in the likelihood of the admission of the leave petition.

Figure 5 shows that while the admission rate in cases heard by benches that did not include the Chief Justice was similar to the global average in our data set, the admission rate in cases that were heard by benches that did include the Chief Justice was substantially higher at $31.2 \%$.

In Figure 6 we see that the admission rate before two judge benches corresponded with the average admission rate (18.5\% against $18.9 \%$ ) but was signi cantly higher when a case was heard by a three-judge bench.

In Figure 7 we can see that the admission rate was relatively high when the appellant was a body corporate (the relative number of cases involving a union or an association 17 out of 1100 - is too small to merit much notice).

The data is a bit more granular when we compare di erent pairs of party type before the SC in Figure 8. In this gure, in each pair, the rst named party type is the appellant 


\section{Bench Size}

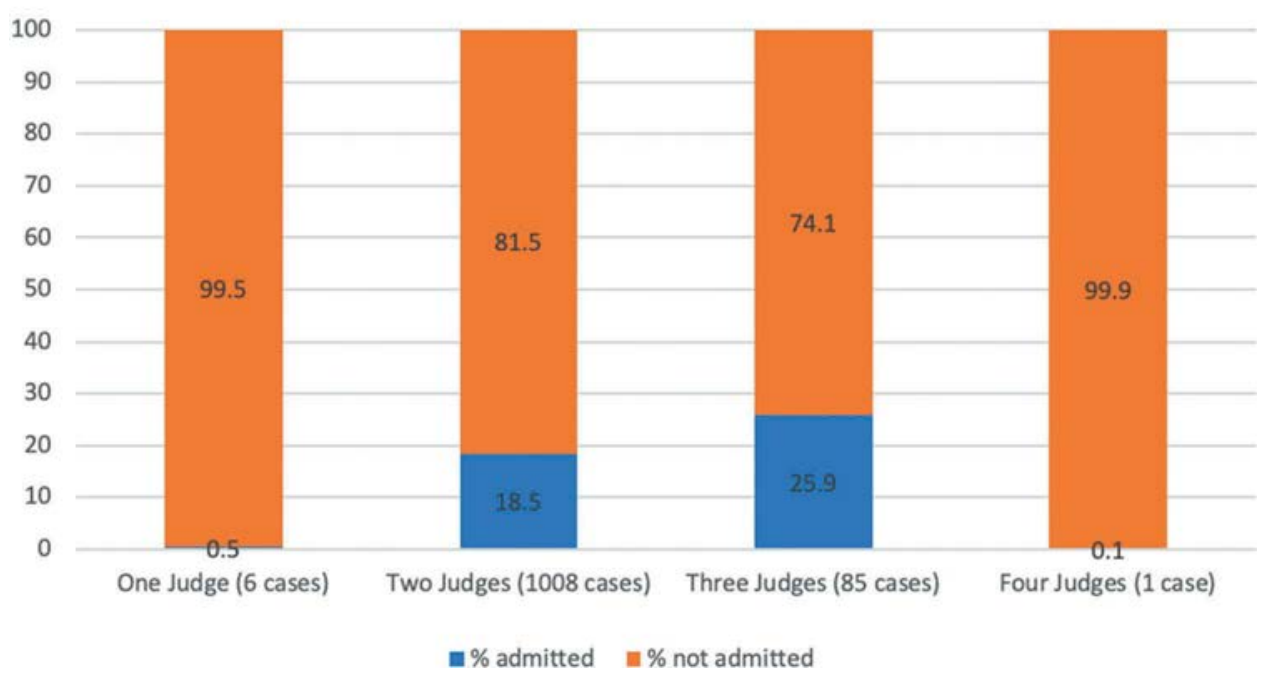

Figure 6. Relation between the size of the admitting bench on the admission rate

and the second named party type is the respondent. We can see that the lowestadmission rate, well below the average admission rate, was seen in cases where an individual appellant brought a case against the State or against a corporate body. Admission rates were signi cantly higher than average when the State sued a corporate body, or a corporate body sued an individual or the State. In general, individual appellants were

\section{Nature of Appellant/Respondent}

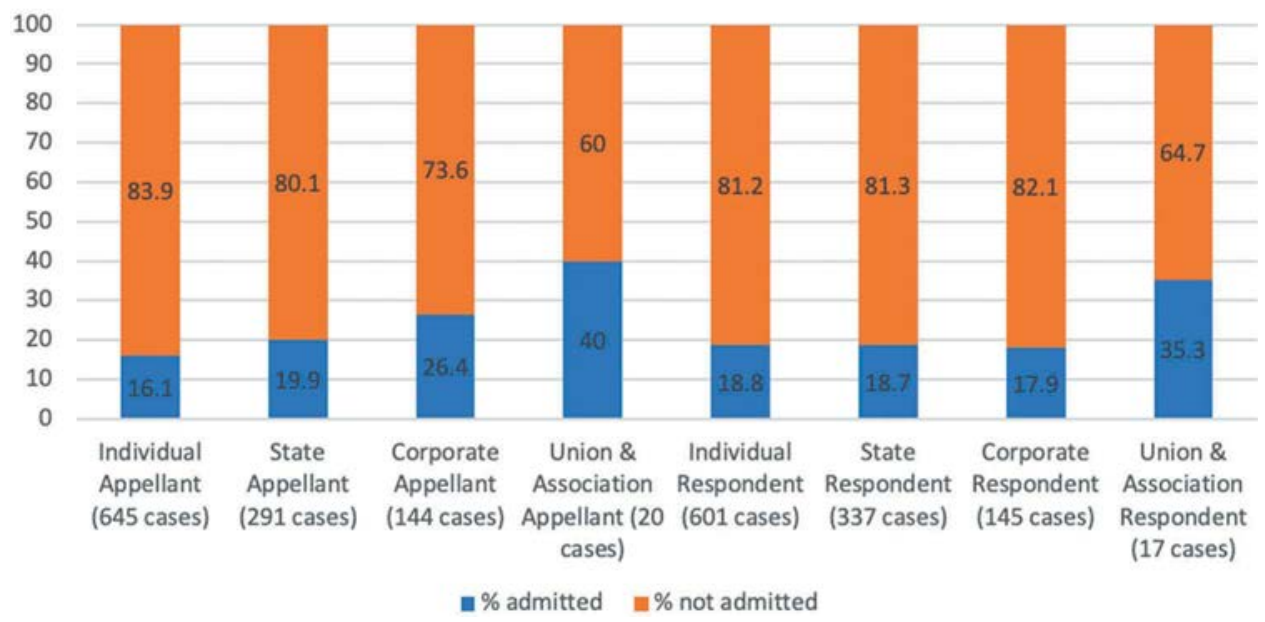

Figure 7. Relation between the nature of the litigants on the admission rate 


\section{Appellant-Respondent Pairs}

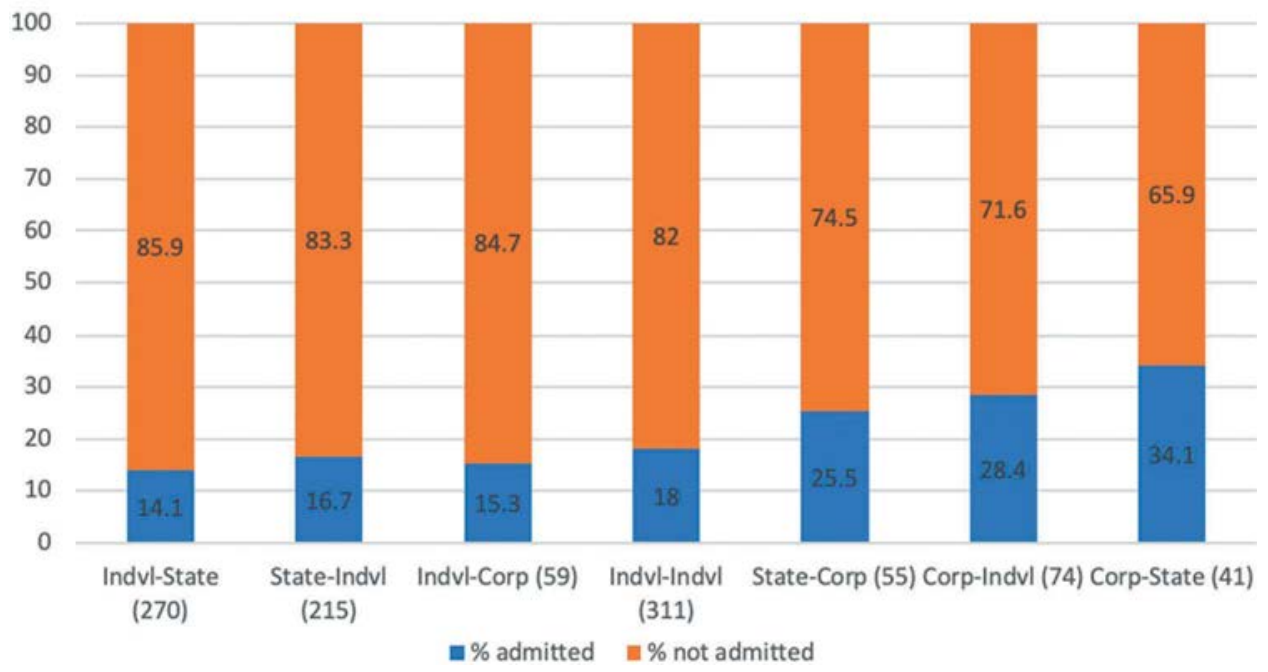

Figure 8. Relation between appellant-respondent pairings on the admission rate

least likely to be successful in getting their case admitted, and corporate appellants most likely, relative to each other. ${ }^{80}$

The descriptive statistics presented in Table 1 and Figures 2-8 suggest that there may be a possible relationship between the admission rate of an SLP (our rst dependent variable) and the following independent variables: (i) the presence of a senior advocate at the admission hearing (denoted by "SA" in the tables and gures), (ii) the presence of the Chief Justice on the admission bench, (iii) the nature of the parties before the SC ("NA" for "nature of appellant" and "NR" for "nature of respondent"), and (iv) the size of the admission bench. All these variables were measured at the time when the admission petition was heard and decided upon (the "admission-hearing", or ' $\mathrm{T}_{2}$ '). A mere correlation, however, is not enough to con dently a rm the relationship between two variables or to make predictions about cases not included in the dataset. Table 2, therefore, presents the results of regression analyses that test whether any of these relationships are statistically signi cant.

Before we look at its conclusions, here is a (hopefully) accessible explanation of what is going on in Table 2 for readers who are not statistically inclined. Because we are interested in the relationship between a dependent variable (Leave Granted) and multiple independent variables (named in the left-most column), ${ }^{81}$ Table 2 depicts four regressions (in the four columns titled "reg (1)", "reg (2)" and so on). All our variables are

\footnotetext{
${ }^{80}$ However, Chandra and others found that the eventual reversal rate of individual-state SLPs is signi cantly lower than that of state-individual SLPs: Chandra and others (n 16) 166. This suggests that the SC is applying a lower admissibility standard for cases brought by individuals against the state when compared to cases brought by the state against individuals. This is compatible with our nding in Figure 8-it is possible for the individual-state pairing to have a very low admission rate despite a low admissibility standard being applied, so long as we allow for the plausibility that individuals are much more likely to bring a really weak claim against the state than vice versa.

${ }^{81}$ The rstrow, titled "Intercept" is notavariable, but a constantused in regressionanalysis. Readers canignore itfor our purposes.
} 
Table 2. Regression for relation between variables in relation to the admissions hearing and the grant of leave at $\mathrm{T}$.

\begin{tabular}{|c|c|c|c|c|}
\hline \multirow[b]{2}{*}{ Independentvariable } & \multicolumn{4}{|c|}{ Dependent Variable: Leave Granted } \\
\hline & reg1(1) & reg1(2) & reg1(3) & reg1(4) \\
\hline Intercept & $\begin{array}{c}0.880 \\
(1.004) \\
0.381\end{array}$ & $\begin{array}{l}0.515 \\
(0.752) \\
0.493\end{array}$ & $\begin{array}{l}1.167 \\
(0.499) \\
0.019^{*}\end{array}$ & $\begin{array}{l}(0.108) \\
16^{* \star *}\end{array}$ \\
\hline SA (Appellant) & $\begin{array}{c}0.482 \\
(0.202) \\
0.017^{\star}\end{array}$ & $\begin{array}{c}0.481 \\
(0.202) \\
0.017^{\star}\end{array}$ & $\begin{array}{c}0.483 \\
(0.201) \\
0.016^{*}\end{array}$ & $\begin{array}{l}0.538 \\
(0.198) \\
0.007^{\star *}\end{array}$ \\
\hline SA (Both) & $\begin{array}{l}1.878 \\
(0.278) \\
1.3 e-11^{\star \star \star}\end{array}$ & $\begin{array}{l}1.874 \\
(0.277) \\
1.41 \mathrm{e}-11^{\star \star \star}\end{array}$ & $\begin{array}{l}1.835 \\
(0.274) \\
2.27 \mathrm{e}-11^{\star \star \star}\end{array}$ & $\begin{array}{l}1.922 \\
(0.271) \\
1.25 \mathrm{e}-12^{\star \star \star}\end{array}$ \\
\hline SA (Respondent) & $\begin{array}{l}1.427 \\
(0.297) \\
1.52 \mathrm{e}-6^{\star \star *}\end{array}$ & $\begin{array}{l}1.417 \\
(0.296) \\
1.75 \mathrm{e}-6^{\star \star \star}\end{array}$ & $\begin{array}{l}1.357 \\
(0.292) \\
3.25 \mathrm{e}-6^{\star \star \star}\end{array}$ & $\begin{array}{l}1.397 \\
(0.290) \\
1.40 \mathrm{e}-6^{\star \star \star}\end{array}$ \\
\hline Chief Justice & $\begin{array}{c}0.536 \\
(0.328) \\
0.102\end{array}$ & $\begin{array}{c}0.635 \\
(0.274) \\
0.020^{\star}\end{array}$ & $\begin{array}{c}0.644 \\
(0.272) \\
0.018^{\star}\end{array}$ & $\begin{array}{c}0.651 \\
(0.271) \\
0.016^{\star}\end{array}$ \\
\hline NA (Corporate) & $\begin{array}{c}0.467 \\
(0.536) \\
0.384\end{array}$ & $\begin{array}{c}0.481 \\
(0.535) \\
0.369\end{array}$ & $\begin{array}{l}0.392 \\
(0.524) \\
0.455\end{array}$ & \\
\hline NA (Individual) & $\begin{array}{l}0.922 \\
(0.510) \\
0.071\end{array}$ & $\begin{array}{c}0.940 \\
(0.508) \\
0.065\end{array}$ & $\begin{array}{c}0.839 \\
(0.499) \\
0.093\end{array}$ & \\
\hline NA (State) & $\begin{array}{c}0.748 \\
(0.532) \\
0.153\end{array}$ & $\begin{array}{l}0.760 \\
(0.531) \\
0.152\end{array}$ & $\begin{array}{l}0.634 \\
(0.510) \\
0.214\end{array}$ & \\
\hline NR (Corporate) & $\begin{array}{l}0.878 \\
(0.587) \\
0.135\end{array}$ & $\begin{array}{l}0.873 \\
(0.586) \\
0.137\end{array}$ & & \\
\hline NR (Individual) & $\begin{array}{c}0.471 \\
(0.552) \\
0.392\end{array}$ & $\begin{array}{c}0.469 \\
(0.551) \\
0.394\end{array}$ & & \\
\hline NR (State) & $\begin{array}{c}0.616 \\
(0.568) \\
0.278\end{array}$ & $\begin{array}{c}0.614 \\
(0.567) \\
0.279\end{array}$ & & \\
\hline Bench size at $T_{2}$ & $\begin{array}{c}0.172 \\
(0.313) \\
0.583\end{array}$ & & & \\
\hline No. of observation & 1100 & 1100 & 1100 & 1100 \\
\hline AIC & 1010.1 & 1008.4 & 1006.1 & 1006 \\
\hline$R 2$ & 0.087 & 0.087 & 0.083 & 0.078 \\
\hline adiusted- $R^{2}$ & 0.078 & 0.079 & 0.077 & 0.074 \\
\hline
\end{tabular}

"categorical" variables (which have values such as "male/female", "true/false", "yes/no" and so on), rather than "interval" variables (such as 1, 2, 3, 4 . . etc). We have therefore conducted a logistic regression with "dummy" variables. When a categorical variable (say "presence of SA") can have values (in our example, 4: a senior advocate was present "only for appellant", "only for respondent", "for both parties", "for neither party"), we need only - 1 dummy variables to denote it. Therefore, in our regression, "SA for 
neither party" does not feature, since it is treated as a baseline. The same is true for "Chief Justice absent" and so on. Which of the variables is selected as a baseline makes no di erence to the outcome of the regression analysis.

Each cell has a set of three numbers. The rst of these numbers is the "coe cient"- if this is positive, it indicates a positive correlation between the independent variable mentioned in the left-most column and the dependent variable; a negative gure denotes an inverse relationship. The middle number in the set is the "standard error". The most important of these numbers for our purposes is the third number: the "p-value". P-value is always a number between 0 and 1, and denotes the "signi cance" of the relationship between the explanatory and the dependent variable - it should be noted that statistical signi cance does not mean the "importance" of the relationship, it instead denotes the level of con dence with which one can say whether a relationship exists or not. More signi cant relations have a p-value closer to 0 . A p-value less than 0.05 is the threshold below which statisticians normally understand a relationship to be borderline statistically signi cant and therefore may permit generalization. P-values below 0.01 are considered statistically signi cant, and those below 0.001 are considered highly statistically signi cant.

All p-values lower than 0.05 are highlighted in bold text in Table 2 . In addition, they are marked by asterisks ("*") next to them. A single asterisk denotes a p-value between 0.01 and 0.05. Two asterisks denote p-value between 0.001 and 0.01 . Three asterisks - denoting relations that are highly signi cant - have a p-value less than 0.001. P-values higherthan 0.5 (i.e., those without an asterisk next to them) are not signi cant. Statistically insignificance does not necessarily indicate that the relationship does not exist - it only suggests that , we did not nd any evidence for such a relationship existing.

Readers without statistical training mainly need to focus on asterisked and emboldened p-value gures - only these suggest statistical signi cance. Apart from this, the only other signi cant item to notice is whether the coe cient - i.e. the rst number in any cell - has a positive or a negative value. A positive value indicates a positive relationship between the dependent and the independent variable, whereas a negative value denotes an inverse relationship between them. The rst row, labelled "Intercept", may be ignored entirely.

In Table 2, we can see that whether a case is admitted by a bench is most signi cantly related to whether the respondent is represented by a senior advocate, or when both parties are represented by a senior advocate ( $\mathrm{p}$-value $<0.001$ ). There also appears to be a strong correlation between a senior advocate appearing for the appellant and the case being admitted ( $\mathrm{p}$-value $<0.01$ but $>0.001$ ). All these relationships are positive - even the relationship between representation of the by a senior advocate and the likelihood of admission.

This last nding - that senior advocates have a statistically signi cant association with admissibility, whichever side they appear for - rules out one possible explanation of the ndings: if it was the case that petitions in which senior advocates were involved were simply more professionally drafted and advocated, we should have seen a higher admission rate for SLPs where the appellant was represented by a senior advocate, but admission rates where a senior advocate appeared for the respondent. Since this is not the case, it seems that admissibility is related to the mere of a senior advocate before a bench, rather than what they have to say. Without qualitative corroboration through interviews, it is di cult to explain the judicial psychology behind this counterintuitive nding. One can only o er some speculations: 
One possibility is that our results are endogenous. In other words, instead of it being the case that cases in which senior advocates appear are more likely to be admitted, it may be the case that senior advocates choose to appear in cases that are more likely to be admitted. This would also explain the counterintuitive nding in relation to the respondents' senior advocates, who may well be taking up more challenging (from the respondents' perspective) cases that already have a high likelihood of admission. A study of factors that senior advocates consider when taking up cases alone can clarify whether endogeneity might be at work here. However, there are reasons to be doubtful about the possibility of endogeneity in these results.

To see why, we should see how the cases that were admitted after being argued by senior advocates fared eventually on substantive appeal. Of the 208 admitted cases, the analysis that follows was informed only by the 107 cases (where we have deemed the appeal to have been "allowed"because the appellant got something from the SC for ling the SLP) and the 73 cases where it was dismissed. Pending, infructuous, withdrawn or extra-judicially-settled cases were ignored for the purposes of this analysis. Figure 9below examines these $180(107+73)$ cases by comparing those that were admitted after being argued by a senior advocate at $T_{2}$ and their eventual success or failure at $T_{3}$.

93 cases in this pool did not have any senior advocate present at the admission stage, whereas the remaining 87 had at least one senior advocate before the SC - as we have seen already, the pool of admitted cases is roughly evenly divided between cases that were admitted after the intervention of at least one SA, and those that did not see any senior advocate intervention. The reversal rate in these 93 cases - without any senior advocate intervention at $\mathrm{T}_{2}-$ is $65.6 \%$ - this is higher than each category of cases where senior advocates were present at the admission hearing. It is also considerably higher than the average reversal rate in the remaining 87 cases taken together, which is $59.4 \%$ (represented by the black horizontal line in Figure 9). Note that the reversal rate in cases admitted after representation by a senior advocate is than the average reversal rate.

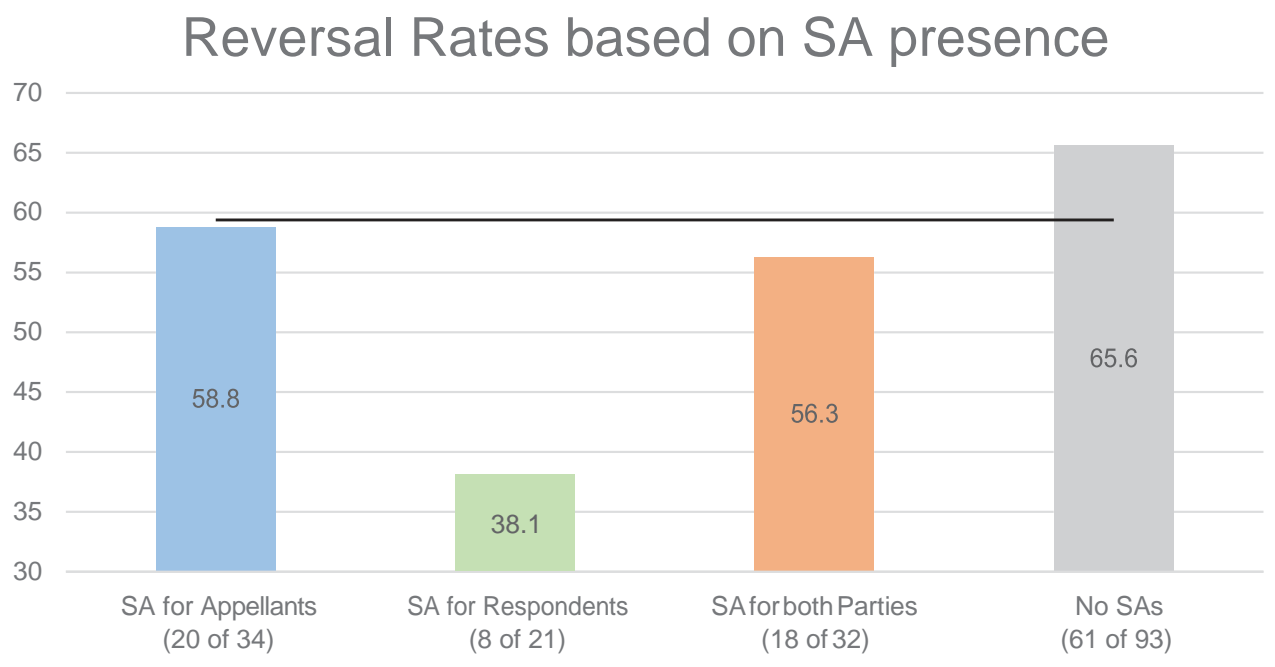

Figure 9. Relation between representation by a Senior Advocate during admissions hearing on the reversal rate 
The implication is that senior advocates are unlikely to be accepting cases that have a higher chance of admissibility, assuming that the main factor in making admissions decisions is the likelihood of the eventual success of the appeal. It is, no doubt, possible that this assumption is incorrect, and that the admitting bench is prioritizing factors other than the likelihood of eventual success. In a superlatively overburdened system, that would be a luxury the SC can ill-a ord as a general matter - but the possibility cannot entirely be ruled out. Note also, that the reversal rate in cases there were admitted without the intervention by a senior advocate was a relatively high $65.6 \%$, and closer to the standards of some apex courts with discretionary jurisdictions identi ed previously. Figure 9 therefore casts doubt on the possibility that our nding in Table 2 in relation to senior advocates is compromised by endogeneity.

Another possible explanation of our counterintuitive result may lie in judicial psychology. It may be that a respondent's senior advocate signals to the judge that the respondent - who already holds most of the cards, as the winner in the lower court and

ghting only a $19 \%$ chance of the case being re-opened - as protesting too much. Perhaps the hiring of an expensive lawyer by the appellant merely suggests desperation, whereas the respondent doing so costs them judicial sympathy? Whatever the causal link, we can have a high level of con dence in the existence of the relationship: the mere presence of a senior advocate - for whichever party - is related to the chances of the SLP being admitted. More research is clearly needed to clarify the nature of this relationship.

It is worth noting that while the presence of senior advocates is by far the clearest predictor for admissions, it may not be the only external predictor. We did not see high levels of statistical signi cance in the other relationships explored in Table 2 - but the absence of evidence does not mean the evidence of absence of these other relationships. A di erent, perhaps larger, dataset may well show that other external factors are also related to admissibility decisions. We should also note that the any positive nding in relation to the presence of the Chief Justice on the admissions bench and to three-judge benches would be particularly susceptible to endogeneity concerns: it is possible that the SC's Registry, which allocates cases to di erent benches, allocates cases with a higher likelihood of admission before these benches. Because of the opaqueness of the basis for the Registry's bench allocation decisions (and the fact that these decisions may be in uenced by the Chief Justice acting in his administrative capacity), qualitative inter- views with forthcoming judges and registrars alone can properly explain this relationship. At any rate, while we cannot rule out these other relationships, we can say with some con dence that the presence of a senior advocate is related to decisions on admissions of SLPs. Senior advocates, therefore, are likely to be playing a key role in the high levels of admitted SLPs in the SC, which in turn is responsible for the cannibalization of the

Court's constitutional jurisdiction.

\section{A way forward}

This exploratory study has probably raised more questions than it has answered. There is clearly signi cant need for further research in some of the issues that have been raised. Even so, we can claim with a fair degree of con dence that:

(1) The admission rates of SLPs in practice is higher than it should be; 
(2) These high admission rates of SLPs impose signi cant costs on litigants, mainly in the form of process delays;

(3) They also impose a huge systemic cost inasmuch as the resources they use squeeze out the SC's constitutional protection function; and

(4) Appearance by senior advocates at admission hearings is positively and signi cantly correlated with the admission of SLPs.

These ndings are worrying, and signal some of what is ailing the system. Let us begin with the rst one: that the SC applies a relatively low threshold to determine the admissibility of SLPs in practice, rather than the doctrinally mandated exceptional-andspecial-circumstances standard. This is a problem mainly because of the reason already identi ed in section II: the opportunity cost of the low admissions bar is the constitutional watchdog function of the SC. It has far less time and resources left at its disposal to attend to its constitutional protection function than it ought to. Could the problem be solved by simply raising the admissions bar so that the SC genuinely starts applying the exceptional-and-special-circumstances standard?

Sadly, not. That might solve one problem but will probably give rise to another. It is often said that a restrictive approach to the SC's special leave jurisdiction will lead to grave injustice to litigants, because High Courts and tribunals often get things wrong. This claim is supported by our ndings. Although a reversal rate of $59.4 \%$ is not high enough to re ect the constitutionally mandated exceptionally high standard, it is high enough warrant a considered systemic solution.

It is, of course, not the case that in every case of disagreement between them the SC's opinion is the correct one and the High Court's mistaken. Every human institution can make a mistake. However, the internal logic of the system is based on the assumption that the reversal of a High Court's order on appeal is a "correction". Testing this assumption is way beyond the scope of this paper, so the best we can do at this stage is to assume some correlation between reversal and correction of a judgement in the SC.

Thus, if High Courts e ectively come to have the last word on most disputes, there will indeed be serious injustice caused. There is a systemic need for an appellate tier above the High Courts - what we need to ensure is that the solution to this systemic need does not come at the cost of the constitutional defence function of the SC. A systemic solution that has often been suggested is the institutional separation of the appellate and the constitutional functions of the SC. An SC bench itself advocated its transformation into a constitutional court, and for its appellate functions to be transferred to a court of appeal. ${ }^{82}$ The Law Commission has, on several occasions, recommended the division of the SC into a constitutional division and four zonal appellate divisions (which will be spread regionally). ${ }^{83}$ The latter solution is preferred by the Law Commission because its implementation might be possible without needing a constitutional amendment. ${ }^{84}$ The

\footnotetext{
${ }^{82}$ Bihar Legal Support Society $v$ Chief Justice (1986) 4 SCC 767.

${ }^{83}$ Law Commission of India, 'Ninety Fifth Report on Constitutional Division Within the Supreme Court: A Proposal For' (1 March 1984) <http://lawcommissiono ndia.nic.in/51-100/Report95.pdf> accessed 14 January 2020. See also Law Commission of India, 'Need for Division of the Supreme Court into a Constitution Bench and Cassation Benches in Four Regions at Delhi, Chennai/Hyderabad, Kolkata and Mumbai' (Report No. 229, August 2009) <http://lawcommissiono ndia.nic.in/reports/report229.pdf> accessed 14 January 2020.

${ }^{84}$ See generally, art 130 of the Constitution of India. This paper expresses no view on whether this is indeed possible without a constitutional amendment.
} 
objective is the same - to achieve an institutional separation of the SC's constitutional and appellate functions. This is going to be expensive and will require an entirely new appellate judicial infrastructure to be created (including an increase in the number of judges on the SC), whichever model of functional separation is adopted. Each appellate division will need to have at least three benches of two or three judges each, and the constitutional division will need at least two ve-judge benches and two three-judge benches. On a conservative count, this will require a further increase in the sanctioned strength of the SCI to at least 44 judges. What is clear is that cleaving the SC into two institutions, separately vested with its appellate and its constitutional functions, is the appropriate response to our rst nding and its implications. Doing so will, at least, permit the SC to better discharge its constitutional functions by ring-fencing them from its overwhelming appellate role.

We saw in section II that the constitutional and the ordinary appellate jurisdictions of the SC are not neatly separated in the . In particular, although most SLPs do not raise constitutional questions, around $4 \%$ of them do. An institutional separation of the SC's constitutional and ordinary appellate functions will therefore require a jurisdictional reallocation. Given the undisciplined historical record of the SC in assessing the scope of its jurisdiction or determining which cases need to be heard by a constitutional bench under art 145(3), any revisiting of its jurisdiction should give preference to clearer rules rather than discretionary standards. Here is one proposal:

The following list includes categories of cases which are essential to constitutional defence and therefore, upon admission, should only be heard by a bench of ve or more judges in the constitutional division/court:

(i) a case involving an actual or potential threat to the established constitutional order or to a fundamental constitutional value (such as democracy, liberty or secularism),

(ii) a case involving a substantial question of law as to the interpretation of the , or an order or Rule issued under the , including any case certi ed under Article 134A of the Constitution,

(iii) a reference from the President under Article 143 of the

(iv) a case involving a challenge to a constitutional amendment, or to an order or rule issued under the

(v) a case involving a challenge to the constitutionality of any provision in a primary legislation (i.e. Acts of Parliament or state legislatures, and Ordinances),

(vi) a case involving a challenge to the invocation or exercise of any emergency power under Part XVIII of the (for example, the dismissal of a state government under Article 356),

(vii) a case involving a dispute between two or more federal units (centre versus state/ union territory, state/union territory versus state/union territory), including any case under Article 131 of the

(viii) a case involving a dispute between two or more high constitutional functionaries or involving the discharge of their functions or a ecting their functional and institutional independence, including:

(a) the President, the Vice President, the Prime Minister, Leaders of Opposition, Governors, Chief Ministers, ministers, 
(b) speakers/chairs or deputy speakers/chairs of legislative chambers,

(c) constitutional or quasi-constitutional o cers - like the Attorney General or the Comptroller \& Auditor General (or their deputies), or

(d) commissioners/governors/chairpersons/directors (or their deputies) of constitutional or quasi-constitutional institutions such as the Election Commission, the Information Commission, the National Human Rights Commission, the Reserve Bank, the Central Bureau of Investigation, the Lokpal, the National Statistics Commission, equality commissions for various marginalized groups, the University Grants Commission, the Finance Commission, media regulators and other "fourth branch" institutions,

(ix) a case involving a point of law on which there is a disagreement between two or more appellate division benches of the $\mathrm{SC},{ }^{85}$ or between two or more smaller benches of its constitutional division, or

(x) a case in which the death penalty might be imposed or con rmed (for as long as the death penalty is understood to be constitutional).

This list does not exhaust all constitutional matters, which will need to go to the constitutional division of the SC after the proposed institutional bifurcation. These other matters may be heard by benches of no less than three judges, unless a hearing by a constitution bench is merited for whatever reason. These remaining cases include the following (provided that they do not already fall within one of the aforementioned constitutionally salient cases):

(i) a writ petition seeking the enforcement of a fundamental right under Article 32 of the Constitution,

(ii) a writ appeal from a judgement of a High Court under Article 226 of the Constitution, if it involves the enforcement of a constitutional right,

(iii) a case involving a challenge to the constitutionality of any executive act or omission, or

(iv) a case involving a question of constitutional law, which cannot be decided without the constitutional law question being answered.

Other eligible appellate cases may be routed to the relevant appellate division. The order on admission or dismissal of a case must record the precise reason for the admission or dismissal of a petition by the constitutional division/court. Both the appellate and the constitutional divisions should be able to assign petitions listed before them to the other division, where appropriate, instead of requiring the appellant to re- petition that division. Needless to say, these proposals are o ered by way of furthering the conversation. More research, experimental pilots, and broad consultation are essential before any of them are adopted fully.

Let us now consider our nal nding: that appearance by senior advocates at admission hearings is positively and signi cantly correlated with the admission of SLPs. Regression

\footnotetext{
${ }^{85}$ This is, strictly speaking, an appellate rather than a constitutional function. But for pragmatic reasons, it is preferable to have one nal court rather than two. A separate nal court of appeal that sits over the appellate divisions will be too expensive and may dilute the authority of the constitutional division.
} 
analysis cannot, on its own, establish causation. So, we can only suspect that senior advocates are playing a docket-distorting role in relation to the SC's SLP jurisdiction. A rmer causal claim will require further research. If con rmed, the presence of senior advocates at admission hearings e ectively creates a large number of false positives in the system, thereby exacerbating the problem of burden and delay, with its concomitant consequences for the litigants as well as for the SC's constitution-defence role. While there may be some justi cation for false positives that, for expressive reasons, provide vulnerable appellants with weak cases a "day in the court", ${ }^{86}$ no such justi cation exists for the use of the presence of a senior advocate at the admissions hearing as a predictor. If anything, vulnerable appellants are less likely to be able to a ord senior advocates than other types of litigants.

If these ndings are con rmed and made more robust in future research, two institutional reform possibilities may be considered - the SC could either bar senior advocates from appearing during admission hearings or it could dispense with oral hearings entirely and decide upon admissibility largely based on written briefs, in at least certain categories of admission decisions. Before we look at these solutions, a caveat: our nding of the presence of senior advocates is limited to civil SLPs. False positives may, at least relatively speaking, be less of a problem in constitutional or criminal cases than in ordinary civil cases. Sure, there is a systemic cost even in these cases, but because the respondent in such cases tends to be the state, the worry about injustice to the respondent due to burdensome transaction costs is mitigated. Furthermore, the proposals to follow can be implemented independently of the proposed institutional division of the SC into constitutional and appellate divisions. If applied after this separation, their application could be restricted only to the civil cases before the appellate division. If applied before any institutional separation, they should apply to all civil SLPs that do not fall within the two aforementioned lists of cases deemed appropriate for the constitutional division.

The rst alternative is for the SC to consider moving to a system of making admission decisions for (non-constitutional) civil SLPs by circulation of written briefs. In many countries that decide on admissibility based on written briefs, such as the United States, Canada and the United Kingdom, judicial clerks often have the key role of writing memoranda on admission petitions in order to make the judicial task more manageable. ${ }^{87}$ The Indian judiciary has become increasingly comfortable with judicial clerks in recent years, making this move more feasible than in the past. Like many other courts, it should also prescribe time-saving rules such as a twenty (or so) page limit on the length of the briefs. Such a move will shift work away from senior advocates (who mainly focus on oral hearings) to talented sections of the junior bar, and reduce the former's distorting in uence on admission decisions. ${ }^{88}$ It should also save the SC considerable time it spends on Mondays and Fridays hearing these petitions. There will have to be a transition period, as the quality of the written briefs currently is generally quite bad. Once the brief begins to matter, the quality should - over time - improve. Judges could retain discretion to refer those petitions for oral hearings in which they need further information or to hear the other party before deciding on admission, as is now the case in Australia. ${ }^{89}$

\footnotetext{
${ }^{86}$ Chandra and others (n 16) 20.

${ }^{87}$ Alarie and Green (n 26) 156.

${ }^{88}$ See generally, Galanter and Robinson (n 7).

${ }^{89} \mathrm{High}$ Court of Australia, 'Changes to High Court Procedures for Considering Applications for Special Leave' <http:// www.hcourt.gov.au/assets/corporate/policies/Special_Leave_Changes.pdf>accessed 14 January 2020.
} 
A possible objection to this solution could be that a public hearing - even a very short one - often exposes blatant injustices and induces a sense of shame that compels a bench to admit a case. This sense of public embarrassment will be absent in decisions based on written briefs alone. A move to decisions based on written briefs could, therefore, substantially increase the number of false negatives - i.e. deserving cases being denied an appeal - and thereby result in injustice in particular cases. The possibility of injustice caused by false negatives can be ameliorated somewhat by requiring that judges record their reasons in writing whenever issuing an order in an admissions petition. Indeed, this should be the case whether the decision is made after a hearing or by circulation of a written brief.

An alternative proposal would retain the current system of oral hearings for all admission decisions but impose a complete ban on all senior advocates from appearing in such hearings. This will obviate the worry that deserving cases will not get a public hearing that the written-briefs-proposal induces. It will provide litigants with a level playing eld, make access to justice somewhat better, and remove the expansionary and distortionary pressures senior advocates put on the SC's docket. The time saved by the SC by this reform will be less than what it might save by a move to decisions based on written briefs, but it will still be considerable because the elimination of senior advocates should see a reduction in false positives that clog the system.

Further research and public debate are needed to determine the feasibility, bene ts, and costs of these and other solutions. Unlike the proposal for institutional separation - which has been actively debated in the public discourse for over three decades - these ideas have not had the necessary airing. What is clear, however, is that the distorting role played by senior advocates is a serious institutional concern that needs an urgent response.

In terms of admissibility criteria and standards, the constitutional and the appellate divisions should apply di erent standards. The constitutional division should apply a straightforward reasonable-prospect-of-success standard. Basically, the only question it should ask in regard to admissibility is whether the petitioner has a reasonable prospect of succeeding if the case is admitted. If she does, the case should be admitted.

The appellate division should admit a petition seeking to invoke its discretionary appeal only if:

(i) the petitioner has a reasonable prospect of succeeding if the case is admitted; and

(ii) either the High Court or tribunal whose judgement is under appeal refused to grant a request to certify that its judgement was t for appeal to the Supreme Court, or the petition concerns a judgement by a court of rst instance and there is no prospect of an appeal to another court; and

(iii) at least one of the following conditions is satis ed:

(a) the case is of su cient public importance;

(b) the case involves a dissenting opinion in one of the lower courts;

(c) the case involves a disagreement between the lower courts;

(d) the case involves an error of law on the face of the record;

(e) the case raises a novel legal issue;

(f) the case con icts with precedent established in a previous judgement of the Supreme Court or a High Court; or 
(g) refusing to admit the petition may interfere with a person's life or personal liberty.

Point (i) alone xes a lower standard than the special-and-exceptional-circumstances doctrine but brings the test in line with actual practice. Points (ii) and (iii) however impose additional procedural and substantive requirements which should permit some checks on the size of the docket. Point (ii) requires that it should be incumbent upon the petitionerto rst ask the High Court's certi cate to appeal, presumably on grounds mentioned inpoint (iii). The High Court's permission or refusal to grant the certi cate should be reasoned - it should clearly identify which of the seven factors mentioned in point (iii) have (not) been satis ed. This will provide some documentary basis to the SC to judge whether the conditions for exercising its discretionary appeal have been satis ed. Needless to say, any petition seeking to invoke this jurisdiction will need to make a clear case that these criteria are satis ed in the instant case.

To sum up, an institutional division of the SC to vest its appellate and its constitutional functions in di erent bodies is essential to stop the former from cannibalizing the latter. The potential docket-distorting role of senior advocates - suggested by the ndings in this paper - is also a serious concern that needs to be attended to urgently. Indian democracy is going through a tumultuous time, and the role the SC plays towards protecting its key constitutional values may well determine the fate of the idea of India.

\section{Acknowledgments}

The author is a Professor of Law at the University of Oxford and The University of Melbourne and a Global Visiting Professor at New York University Law School. I thank Azim Pemji University for providing the research grant to undertake this project, and to the Australian Research Council for supporting my Future Fellowship, which helped me nish this project. I am also grateful to Amba Kak for helping with the research design and the pilot study for this project and for cross-checking coding, to Chandni Chawla for coding the 1100 cases, to Mohit Desai and Siru Wang for statistical analysis, and to Mihika Upadhyaya for clarifying several issues concerning econometrics and helping with tables and gures. Many other friends, colleagues and practitioners-especially Nick Robinson, Alok Prasanna Kumar, Gautam Bhatia, Harish Narasappa, Sushant Sinha, David Law, Kate O'Regan, Tom Ginsburg, Shawn Rajanayagam, Aparna Chandra, William Hubbard and Sai Vinod-shed light on diverse aspects of the project, for which I am thankful. The two anonymous reviewers, and the handling editor TT Arvind, also have my deep gratitude for their carefully reading, patient corrections, and extremely helpful insights. Mistakes remain mine.

\section{Funding}

This work was supported by the Azim Premji University [Research Grant]; Australian Research Council [FT170100358]. 


\section{University Library}

\section{- M M N E R VA A gateway to Melbourne's research publications}

Minerva Access is the Institutional Repository of The University of Melbourne

Author/s:

Khaitan, $\mathrm{T}$

Title:

The Indian Supreme Court's Identity Crisis: A Constitutional Court or a Court of Appeals?

Date:

2020

Citation:

Khaitan, T. (2020). The Indian Supreme Court's Identity Crisis: A Constitutional

Court or a Court of Appeals?. Indian Law Review, 4 (1), pp.1-30. https://

doi.org/10.1080/24730580.2020.1730543.

Persistent Link:

http://hdl.handle.net/11343/242044 